\title{
Quantifying community resilience in South Sudan: The FEED project (Fortifying Equality and Economic Diversification)
}

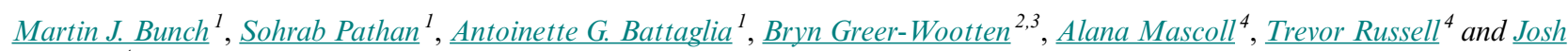 \\ Folkema $^{4}$
}

\begin{abstract}
An analysis of community resilience in South Sudan, based on household survey data, is presented in this paper. The data were collected as part of the Fortifying Equality and Economic Diversification (FEED) Project (a consortium project of World Vision, Oxfam, and CARE). The goal of the project was to meet basic food security needs and reduce vulnerability amongst empowered communities and households in Greater Bahr el Ghazal and the Equatorias in South Sudan. Three dimensions of resilience (absorptive, adaptive, and transformative) were analyzed using principal component analysis (PCA). In this analysis, the components identified those characteristics of households, such as avoidance of negative coping strategies, capacity for disaster management at the community level, and access to social capital, that are important factors in resilience with respect to food security. Some of the principal components point to targets for programming. For example, in times of food scarcity, programming could target capacity building to construct storage facilities that are resistant to pests, rain, and dampness. This finding supports positive coping strategies, e.g., drawing upon stores of food in times of food scarcity. Similarly, building social capital is another programming opportunity indicated by these results, because drawing upon social networks to feed household members is a better coping strategy than, for example, selling liquid assets, harvesting immature crops, or simply going hungry. Furthermore, the analysis using PCA lends itself to the development of indices of resilience. Household scores on three resilience indices are produced: absorptive, adaptive, and transformative resilience. This allows for the identification of most and least resilient households. With this approach household scores on these indices can be aggregated to higher levels, such as the village level.
\end{abstract}

Key Words: community resilience; development resilience; food security; international development; principal component analysis; resilience; South Sudan

\section{INTRODUCTION}

\section{Context}

A resilience analysis of households and communities in several states in South Sudan, in the context of a humanitarian aid and development project intended to address food security and gender equality, is presented in this paper. The Republic of South Sudan is an oil-rich country that is bordered by Sudan, Ethiopia, Kenya, Uganda, the Democratic Republic of Congo, and the Central African Republic. In 2005 the Sudanese People's Liberation Movement and the Government of Sudan signed the Comprehensive Peace Agreement, ending Africa's longestrunning civil war and starting a short-lived era of peace for the region that would soon become South Sudan. During the peace years, the shift from humanitarian support to recovery efforts intensified. The Republic of South Sudan is the world's newest nation, gaining independence after peacefully seceding from Sudan in July 2011. By December 2013, as a result of domestic factors and regional influences, the country was once again embroiled in civil conflict, which despite multiple rounds of peace negotiations, continues to this day. According to the UN Office for the Coordination of Humanitarian Assistance, in 20197.1 million of South Sudan's 11.7 million people are in dire need of some form of humanitarian assistance:

\section{Years of conflict, displacement and underdevelopment have limited people's livelihood opportunities, marginalized women's formal employment opportunities, and weakened families' ability to cope with the protracted}

crisis and sudden shocks, like the death of a wage earner or loss of cattle. The livelihoods of 80 per cent of people are based on agricultural and pastoralist activities. Farmers, who are mostly women, and their families have been displaced from their fertile lands. Annual cereal production has reduced by 25 per cent from 2014 to 2017 , leaving a nearly 500,000 metric tons deficit for 2018. Over 80 per cent of the population lives below the absolute poverty line and half the population will be severely food insecure between January and March 2019 (United Nations Office for the Coordination of Humanitarian Affairs 2018:2).

The resumption of conflict necessitated a shift to life-saving humanitarian aid; however, there was an attempt to retain the development gains made in the stable parts of the country. It is this context in which World Vision led a consortium of nongovernmental organizations (NGOs), with Oxfam and CARE, to implement the Fortifying Equality and Economic Diversification (FEED) project. FEED was a food security, livelihoods, and gender equality project implemented from April 2015 to March 2018. It supported 215,144 people $(135,645$ females and 79,499 males) with the ultimate goal "to meet basic food security needs and reduce vulnerability amongst empowered communities and households in seven of the former states in South Sudan - Eastern Equatoria, Central Equatoria, Western Equatoria, Lakes, Warrap, Northern Bahr el Ghazal and Western Bahr el Ghazal" (World Vision Canada et al. 2018:6; see Fig. 1). The project aimed to reduce the vulnerability of the most

${ }^{1}$ Faculty of Environmental Studies, York University, ${ }^{2}$ Department of Geography, York University, ${ }^{3}$ Institute for Social Research, York University, ${ }^{4}$ World Vision Canada 
marginalized peoples in the local population and to increase the resilience of the population to absorb both natural and humanmade shocks and stressors.

Fig. 1. States in South Sudan in 2015 (some boundaries, e.g., with Sudan, are disputed). Fortifying Equality and Economic Diversification (FEED) States are highlighted in grey.

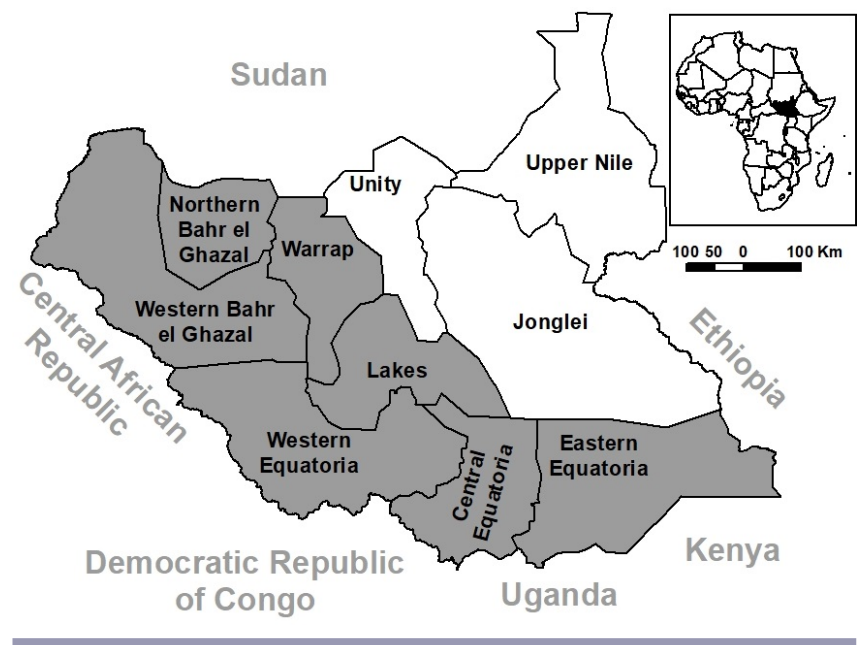

To achieve this goal FEED adopted "resilience" as its theory of change. The theory of change is a methodology that informs the planning, intervention, and evaluation of a project. It "depicts a causal package of activities plus assumptions that together are expected ... to contribute to the intended results" (Mayne 2015:127). The FEED consortium required a framework to inform and validate the approach to building resilience. Validating the approach would help the consortium invest time and financial resources in the most beneficial activities. Thus, World Vision engaged the (non-World Vision) authors of this paper to undertake an assessment of their resilience framework and to analyze data from a survey that was developed and administered by their field team in South Sudan as part of the FEED project.

The purpose of the study presented here was to validate the FEED project's approach to resilience. To this end we describe the resilience framework adopted by FEED, employing three resilience domains (absorptive, adaptive, and transformative), and present an analysis of household and community-level responses to the FEED survey of resilience in South Sudan using a principal components analysis (PCA) approach. From this work, we draw conclusions and make recommendations for programming in South Sudan that reinforce the work of the field team and support the development of the next phase of FEED.

\section{The resilience framework}

The term resilience has found its way into the lexicon of a variety of disciplines, such as psychology, ecology, engineering, and planning. In doing so, the term has taken on related but somewhat different meanings. In psychology, resilience is considered an individual or personal trait (Kulig et al. 2013) or a process of positive adaptation within the context of chronic adversity, whereas for ecological systems, "[r]esilience determines the persistence of relationships within a system and is a measure of the ability of these systems to absorb change of state variables, driving variables, and parameters, and still persist" (Holling 1973:17). This view of ecological resilience emphasizes far from equilibrium system states and the potential for tipping points and system transformation, and is distinct from engineering (and economic) resilience that focuses on stability near equilibrium steady states and the return to stability in the face of disturbance (Holling 1996).

What these definitions have in common is that "resilience is a measure of the ability of a system to withstand stresses and shocks - its ability to persist in an uncertain world" (Perrings 1998:221). Social-ecological definitions of resilience have evolved from these traditions, including ideas of both system transformation and of persistence in the face of change (Olsson et al. 2015). Folke (2016), for example, states that "[r]esilience is the capacity of a system to absorb disturbance and reorganize while undergoing change so as to still retain essentially the same function, structure, and feedbacks, and therefore identity, that is, the capacity to change in order to sustain identity."

For ecological and social-ecological resilience, resilience is seen as neither positive nor negative. A system could be resilient but "maladaptive," i.e., organized around an attractor that is undesirable (Gunderson and Holling 2002). In many applications that focus on community or social systems (such as in international development practice), however, resilience takes on a slightly different nature. Like the definitions in psychology, resilience in a social science or international development setting often refers to positive (desirable) changes in a system (see, e.g., Berkes and Ross 2013, Maclean et al. 2014, Constas et al. 2014a). In "community resilience," this is applied to larger groups of people (as opposed to the individual orientation of psychological resilience). Norris et al. (2008:130) note that for communities (having geographic boundaries and a shared fate) resilience is "a process linking a set of adaptive capacities to a positive trajectory of functioning and adaptation after a disturbance." This is also demonstrated by Barrett and Constas (2014), in developing their theory of "development resilience," which identifies regimes or attractors in development contexts (the humanitarian emergency zone, chronic poverty zone, and nonpoor zone) that are useful in understanding poverty traps and informing intervention to transition out of undesirable regimes in such contexts. To Barrett and Costas (2014:14626), "[d] evelopment resilience is the capacity over time of a person, household or other aggregate unit to avoid poverty in the face of various stressors and in the wake of myriad shocks."

Furthermore, studies in the social sciences analyze power dynamics, agency, and conflict, which also influence the use of the resilience concept (CARRI 2013, Olsson et al. 2015). Quinlan et al. (2016) review a number of such perspectives on resilience: they identify a variety of approaches to resilience assessment and measurement, and make the point that one's approach to resilience assessment and measurement must align with how resilience is understood and defined. This is reflected in the survey tool employed by FEED in South Sudan, which, among other things, explores gender dynamics and conflict experienced by households. In such situations, resilience is seen as the ability of a group or community to adapt to shocks and stresses in the system: it is understood that what defines a "resilient" community or system largely depends on the goals to be achieved (Carpenter et al. 2001, Alinovi et al. 2008, Quinlan et al. 2016). 
The resilience context analysis for South Sudan (DFID 2011, as cited in Papavero et al. 2015:35) refers to shocks as "sudden events impacting the vulnerability of a system and its components." They identify shocks to food security in South Sudan to include high food prices and other economic shocks; insecurity and violence such as the civil war; local conflicts and armed youth; hydrometeorological shocks such as drought and floods; and human, animal, and crop disease outbreaks. The impact of shocks will be worsened by the presence of stressors. Stressors are,

\begin{abstract}
either long-term trends that undermine the potential of a given system and increase the vulnerability of the actors within it, or slow-onset hazards that develop and pass a 'tipping point' to become extreme events. By diminishing individual/household/community capacity to withstand shocks, and increasing the negative impacts of these shocks, stresses undermine resilience. (Papavero et al. 2015:45).
\end{abstract}

In South Sudan these include endemic disease and morbidity related to poor health and sanitation; pressures related to the hosting of displaced persons; limited basic infrastructure such as roads and access to services; limited access to quality education; poor access to water and sanitation; lack of social welfare or protection; sexual and gender-based violence (SGBV); risks to children such as SGBV, early labor, child marriage, and recruitment into armed groups; social or cultural events that deplete household assets, such as weddings; low productive capacity and technology; youth unemployment and alienation; and limited employment opportunities.

The FEED consortium's understanding of resilience recognizes the roots of the concept in complexity science, as is most strongly expressed in the fields of ecological and social-ecological resilience. It is influenced by resilience conceptions in climate change adaptation, conflict sensitivity, and disaster risk reduction (Folkema 2015, unpublished manuscript), but is oriented to the household and community level and resembles more the description of "community resilience" and "development resilience" indicated above. It draws from approaches to resilience in the development field expressed by the World Food Programme (2015), and Humanitarian Emergency Response Review (Ashdown 2011), as well as the UK Department for International Development, United States Agency for International Development, the European Union, the United Nations Development Programme, the World Bank, and the United Nations Office for the Coordination of Humanitarian Affairs (Folkema et al. 2013). These agencies express an approach to understanding, assessing, and measuring resilience that correspond to conceptions of development resilience and community resilience (Constas et al. 2014a, b, Barrett and Constas 2014, Béné et al. 2015). These approaches identify three domains of resilience: absorptive, adaptive, and transformative. Béné et al. (2015:10) describe these as follows:

(1) an absorptive capacity that includes all the various risk management strategies by which individuals and/or households moderate or cope with the impacts of shocks on their livelihoods and basic needs; (2) an adaptive capacity that reflects the 'capacity to learn, combine experience and knowledge, adjust responses [in a proactive way] to changing external drivers and internal processes, and continue operating' (Berkes et al. 2003); and (3) a transformative capacity, i.e., the capacity to create an enabling environment through investment in good governance, infrastructure, formal and informal social protection mechanisms, basic service delivery, and policies/regulations that constitute the necessary conditions for systemic change.

The World Food Program (WFP 2015) undertook a resilience context analysis for South Sudan and identified absorptive, adaptive, and transformative capacities for South Sudan that are presented in Table 1. The FEED consortium's conception of resilience and the WFP study informed the development of the survey tool administered at the household level, described briefly below.

Table 1. Absorptive, adaptive, and transformative capacities identified for South Sudan in the World Food Program's resilience context analysis (2015).

\begin{tabular}{|c|c|c|}
\hline Absorptive & Adaptive & Transformative \\
\hline $\begin{array}{l}\text { Coping strategies (e.g., } \\
\text { reducing meals/portion } \\
\text { sizes, selling household } \\
\text { assets, begging, } \\
\text { withdrawing children } \\
\text { from school, etc.) }\end{array}$ & $\begin{array}{l}\text { Livelihood risk } \\
\text { diversification }\end{array}$ & $\begin{array}{l}\text { Access to markets and } \\
\text { infrastructure }\end{array}$ \\
\hline Livestock ownership & $\begin{array}{l}\text { Improved access to } \\
\text { productive and fertile } \\
\text { land }\end{array}$ & $\begin{array}{l}\text { Access to quality } \\
\text { education }\end{array}$ \\
\hline Expenditure & $\begin{array}{l}\text { Income source } \\
\text { reliability and } \\
\text { sustainability }\end{array}$ & $\begin{array}{l}\text { Support for land and } \\
\text { livelihoods }\end{array}$ \\
\hline Psychosocial strength & $\begin{array}{l}\text { Skilled household } \\
\text { labor }\end{array}$ & $\begin{array}{l}\text { Access to water and } \\
\text { sanitation }\end{array}$ \\
\hline $\begin{array}{l}\text { Savings and informal } \\
\text { safety nets }\end{array}$ & $\begin{array}{l}\text { Seasonal migration } \\
\text { and remittances }\end{array}$ & $\begin{array}{l}\text { Access to health } \\
\text { services }\end{array}$ \\
\hline \multirow[t]{3}{*}{$\begin{array}{l}\text { Conflict management } \\
\text { and justice systems }\end{array}$} & $\begin{array}{l}\text { Educated household } \\
\text { head }\end{array}$ & $\begin{array}{l}\text { Access to credit and } \\
\text { formal safety nets or } \\
\text { social protection }\end{array}$ \\
\hline & $\begin{array}{l}\text { Early warning and } \\
\text { disaster mitigation } \\
\text { systems }\end{array}$ & $\begin{array}{l}\text { Youth employment and } \\
\text { empowerment }\end{array}$ \\
\hline & & $\begin{array}{l}\text { Women's } \\
\text { empowerment, } \\
\text { attitudes, and } \\
\text { aspirations } \\
\text { Community networks }\end{array}$ \\
\hline
\end{tabular}

\section{METHODS}

\section{Measuring resilience}

FEED employed an approach to the measurement and analysis of resilience that included structured interviews, key informant interviews, focus group discussions, and literature reviews. We are concerned primarily with the structured interviews, which involved a survey instrument administered at the household level, which generated responses to questions organized around the three dimensions of resilience:

1. Absorptive dimension: (a) coping strategies; (b) knowledge to manage hazards; (c) knowledge to manage environmental resources; (d) assets (land, livestock, farm tools); and (e) hunger period; 
2. Adaptive dimension: (a) ability to provide basic needs; (b) income; (c) agricultural sales; (d) income generation; (e) yields; (f) dietary consumption; (g) dietary diversity; and (h) level of education; and

3. Transformative dimension: (a) access to extension services; (b) knowledge of agricultural technologies; (c) access to inputs; (d) market access; (e) financial services access; (f) attitudes on gender equality; (g) equitable ownership and control of resources; (h) women in leadership; (i) women's participation and influence; and (j) community service organization (CSO) capacity.

The identification of these three dimensions of resilience provided a useful way to organize the survey and the analysis. The choice and assignment of these variables, e.g., to only one category and not others, was informed by the WFP resilience context analysis (2015). On the other hand, the WFP recognized that these categories are not mutually exclusive. They are analyzed in separate categories, however, because in the WFP analysis variables assigned to each category were primarily associated with resilience capacities that operate at different temporal scales, "absorbing or simply coping in the short term, adapting in the medium term, and transforming structurally over the long term" (WFP 2015:77). This assumption is important to note in terms of the subsequent analysis.

While the survey itself was oriented to the data collection of respondents as individuals representing households, the FEED project team also conducted complementary situational analysis to support an understanding of regional and national policy and the ongoing conflict. The consortium also carried out a gender assessment and market analysis study (Wasaga 2015a,b).

\section{Data and its limitations}

Kenwell International was contracted to administer the baseline survey at the start of the project. They trained eight teams of 185 enumerators (148 men and 37 women) across the World Vision, Oxfam, and CARE areas of implementation (Wasaga 2015a). After removing two records because of some missing items, 817 households (585 male-headed and 232 female-headed) were interviewed. These households were distributed in 63 bomas (villages), 38 payams (subcounty units of at least 25,000 population), nine counties, and seven states. Enumerators used Datawind and Samsung tablets with Open Data Kit (ODK) software programmed for the collection of data from household surveys.

The administration of this survey generated a large dataset of nearly one thousand variables (including alternative responses to individual questions), and 817 records (households) [ $817 \underline{\mathrm{x}} \sim 1000]$. These data allowed some triangulation using multiple questions to estimate relationships or states, e.g., household access to financial services, exposure to external shocks. It also provided scope for the elimination of variables with faulty data, while maintaining a high likelihood that the remaining data could be used to explore the targeted phenomena.

One of the limitations of this data set is that the survey was not designed for quantitative analysis using standard parametric statistical methods. A number of analytical problems were thus engendered:
1. The construction of the survey instrument without consideration for quantitative analysis led to the generation of a very large number of null values in the data set. Many of these null values should have been (or were likely to be) negative responses to questions. Others were skipped questions (potentially a fieldwork issue). Although some were salvaged by data manipulation techniques, many items/ questions were not useable for quantitative analysis;

2. Many responses led to data distributions that violated the assumptions of parametric statistical tests, i.e., they were not normally distributed, and could not be transformed into acceptable distributions. These had to be removed from the analysis, after extensive discussions about their exclusion;

3. The generation of representative samples was not considered in the sample design. Even if they had been, we do not know the overall population numbers of the bomas and payams sampled, and so we cannot determine what would have been an appropriate sample size. Although this is a common problem in survey research in such environments, the results of this work cannot be said to have employed a representative sample. The sample sizes themselves, however, are large enough to counteract this problem to some extent;

4. Some questions were only administered to female respondents. Typically, for quantitative analysis, this would require us to either exclude all cases where male respondents were interviewed, or to exclude all of the questions that were administered only to some (female) respondents. In this situation, after discussion with, and the guidance of, a statistical consultant, we were able to salvage some of these data by considering null (male) responses as neither yes nor no (that is, neutral) and placing the responses on an integer scale. This allowed us to proceed with a fuller dataset but reduces overall confidence in the data; and

5. Many binary and categorical variables led to an overrepresentation of null values in the dataset. For many variables these zero-frequencies also reduce the predictive power of any single variable and lead to problems with multicollinearity. Some binary values were also unbalanced (which we defined as one value accounting for greater than $90 \%$ of responses). On the advice of a statistical consultant and after extended discussions, we removed these variables from the analysis.

In order to conduct a reasonably precise statistical analysis, after addressing these issues and removing any records with a null response, we obtained three useable datasets: (i) comprising 817 records and 44 variables for absorptive resilience; (ii) 800 records and 23 variables for adaptive resilience; and (iii) 804 records and 30 variables that address transformative resilience. These three datasets correspond to the assignment by FEED staff of the three sets of variables (after WFP 2015) that they associated with the three types of resilience. It is believed that this assignment was appropriate for the current study.

\section{Method of analysis}

After a review of the data set, principal components analysis (PCA) was selected as the tool to further understand the South Sudanese information. PCA is a common multivariate statistical 
technique, which extracts components (factors) from a covariance or correlation matrix (Lindeman et al. 1980, Abdi and Williams 2010). This is an approach to reducing dimensionality in the original dataset, producing a new (smaller) set of orthogonal (uncorrelated) variables, while retaining as much of the original variance as possible (Groth et al. 2013). PCA can be used (1) to summarize a large number of original input variables with as few principal components as possible, by means of a mathematical orthogonal transformation of the input data; and (2) to represent an underlying latent variable for which the original variables act as surrogates or indicators (Cliff 1987). Although, in this work, variables have been associated with absorptive, adaptive, or transformative resilience concepts, and analyzed separately in three different datasets, within each analysis the components (latent variables) are generated from the data and are not defined a priori. The meanings of these components are interpreted by the researcher from the loadings (similar to regression coefficients) of the original variables on the respective principal components.

PCA also lends itself to the development of indices of resilience. Component scores can be computed for each household by multiplying its original data value for each variable by the coefficient of that variable on any principal component, and then summing across all variables to produce a component score for the household. Doing this for all variables and all the retained principal components provides a set of component scores for a household. These are usually summed for each household, and scores for all households are then normalized for each component. The normalized data ("standard scores" or "z-scores"), facilitate comparison of households in the dataset within and across resilience categories, allowing most and least resilient households to be identified. These household scores can be aggregated to higher levels, if appropriate.

Another advantage of the PCA approach is that it is robust (relatively) with respect to violations of the standard assumptions of parametric statistical techniques (Johnson and Wichern 1992). This is valuable when dealing with problematic data, which was the case with FEED. Aggregation of data is not necessary until the very end of this process, and only if the analyst wishes to produce resilience scores at aggregation levels higher than the household level. Thus, PCA permits close proximity to the data from the beginning of the analysis to the final production of the results. Finally, if independent variables are identified, this technique produces a relatively manageable set of component scores that can be used in further analysis, e.g., in regression modeling.

A shortcoming of PCA is that the meaning of the principal components generated must be interpreted using the loadings of the input variables on the components. This interpretation is not always obvious and can sometimes seem nonsensical, particularly for less strong components that do not explain much of the variance in the input dataset. Close familiarity with the phenomena under investigation, e.g., with the field settings in which the original data were collected, may be necessary to interpret the results. There is no hard and fast rule to determine which components are meaningful and which are not. Instead, there are some rules of thumb that are used as guidelines, such as the rule of eigenvalues (sum of squared loadings) being equal to or greater than unity, or that the proportion of variance explained by a component should be greater than $5 \%$, as well as the visual interpretation of scree plots, etc. In fact, often some combination of all three rules is employed in interpreting (labeling) the components, which is basically a sense-making endeavor.

\section{RESULTS}

PCAs of the three South Sudan datasets produced results in three categories: absorptive, adaptive and transformative resilience. Each category of variables comprised a separate dataset, with variables identified by FEED staff that relate to one of these three categories of resilience capacities, or the impact/response to shocks and stresses that might indicate the resilience or vulnerability of households and communities.

Table 2 summarizes the results of the three PCA analyses and presents identifying labels for the principal components in each resilience category, i.e., those PCs that account for the highest proportions of the variance in the input datasets. The labels given to these components attempt to capture the meaning of these latent variables as interpreted from the component loadings (regression coefficients or weights) of the input variables on the component. For example, PC1 in the Absorptive Resilience category is defined, at one end of the latent continuum, by negative weights on variables such as restriction of consumption by adults so that children can eat more, sending household members to beg, harvesting immature crops, and purchasing food on credit; and at the other end of the continuum by positive loadings on variables, such as relying on help from a friend or relative, sending household members to eat elsewhere, gathering unusual types or amounts of wild food, and relying on casual labor, i.e., accessing social capital and other more positive strategies to provide food. Households with high positive scores on this PC are those that avoid negative coping strategies in times of food scarcity. In comparison, households with low scores on PC1 do not use (or perhaps do not have access to) positive coping strategies. Appendix 1 provides the full set of principal components with the loadings of variables that define each PC, i.e., those having loadings $\geq 0.3$, and their interpretations.

Table 2. Overview of principal component analysis (PCA) results for absorptive, adaptive, and transformative resilience variables of the South Sudan datasets.

\begin{tabular}{lccc}
\hline \hline & $\begin{array}{c}\text { Absorptive } \\
\text { Resilience }\end{array}$ & $\begin{array}{c}\text { Adaptive } \\
\text { Resilience }\end{array}$ & $\begin{array}{c}\text { Transformative } \\
\text { Resilience }\end{array}$ \\
\hline $\begin{array}{l}\text { No. of Input variables } \\
\text { Principal components }\end{array}$ & 44 & 23 & 30 \\
$\begin{array}{l}\text { retained } \\
\text { Total variance explained }\end{array}$ & 11 & 8 & 9 \\
\hline
\end{tabular}

The results of these analyses describe the situation of households at the time of the survey in 2015. Effectively, this produced two kinds of results. First, PC scores can be used to create resilience indices that can identify households that are more or less resilient, compared to the other households that were interviewed. The methodology also allows for the aggregation of households to higher spatial levels, to identify, for example, village or county populations that are more or less resilient. Tables 3-6 present the empirical resilience indices for four levels of aggregation. As 
indicated above, these calculations are not based on a sample design intended to generate representative samples and can thus be regarded as indicative at best.

Table 3. Average z-score values for each category of resilience, as organized at the state level, for the Fortifying Equality and Economic Diversification (FEED) Project dataset, 2015. ${ }^{\dagger}$

\begin{tabular}{lccc}
\hline \hline State & Absorptive & Adaptive & Transformative \\
\hline Central Equatoria & 0.22 & 0.02 & 0.15 \\
Eastern Equatoria & -0.04 & 0.12 & 0.22 \\
Lakes & -0.14 & -0.27 & 0.10 \\
Northern Bahr el Ghazal & 0.02 & 0.01 & 0.51 \\
Warrap & -0.43 & -0.12 & -0.41 \\
Western Bahr el Ghazal & -0.09 & -0.27 & 0.41 \\
Western Equatoria & 0.33 & 0.14 & 0.05 \\
\hline
\end{tabular}

${ }^{\dagger}$ Scores presented are standard scores or z-scores. These are based on the normal distribution such that a value of 0 is the mean, 1 is one standard deviation from the mean, etc.

Table 4. Average z-score values for each category of resilience, as organized at the county level, for the Fortifying Equality and Economic Diversification (FEED) Project dataset, 2015. ${ }^{\dagger}$

\begin{tabular}{lccc}
\hline \hline County & Absorptive & Adaptive & Transformative \\
\hline Awiel East & 0.02 & 0.01 & 0.51 \\
Gogrial West & -0.36 & -0.10 & -0.28 \\
Juba & 0.22 & 0.02 & 0.15 \\
Tambura & 0.29 & 0.17 & 0.05 \\
Tonj South & -0.48 & -0.13 & -0.51 \\
Torit & -0.04 & 0.12 & 0.22 \\
Wau & -0.12 & -0.27 & 0.42 \\
Wulu & -0.14 & -0.27 & 0.10 \\
Yambio & 0.36 & 0.11 & 0.04 \\
\hline
\end{tabular}

${ }^{\prime}$ Scores presented are standard scores or z-scores. These are based on the normal distribution such that a value of 0 is the mean, 1 is one standard deviation from the mean, etc.

Note as well that these indices are generated only from the dataset analyzed in this work and have no external referents. As such, they are relative to each other and should not be compared to scores generated from any analysis of different datasets.

The second kind of result produced in this analysis is the identification and definition of the principal components, latent variables for which the input variables are surface-level indicators. The empirical PCs describe characteristics of households and communities (and to a lesser extent the wider social-ecological system) that contribute to various kinds of resilience (Table 7). These are defined by the component loadings (weights) of input variables that measure aspects of resilience capacities and exposure or response to shocks and stressors. This allows households and communities to be identified that are more, or less, resilient in various ways in each category. FEED personnel familiar with the field situation in South Sudan participated in the identification and labelling of these PCs.

\section{DISCUSSION}

\section{Supporting and informing programming}

The principal components produced in this analysis identify characteristics of households, such as their avoidance of negative coping strategies, capacity for disaster management at the community level, and access to social capital, that are important factors in resilience with respect to food security. Some of the principal components point to targets for programming. For example, in times of food scarcity, programming could target capacity building to construct storage facilities that are resistant to pests, rain, and dampness. This would support the positive coping strategies that are associated with Absorptive Resilience PC1 (described above and in Appendix 1), such as drawing upon stores of food in times of food scarcity. Such results can be used to identify households that are less or more resilient in terms of coping strategies. But this component also points to targets for programming and validates some of the work done by World Vision since the 2015 survey was undertaken. This is due to work to reinforce, and to make possible, positive coping strategies. Thus, the FEED project has established and strengthened the community postharvest handling storage and management systems, establishing 322 community postharvesting facilities and training 2916 persons on postharvest handling and storage. This would have been higher if not for high levels of insecurity and inaccessibility in some project areas (World Vision Canada et al. 2018). Such work by the FEED project staff led one project beneficiary to state in November of 2017, "We no longer fear July," which in the past has been a month of scarcity.

Table 8 summarizes results from the principal components analysis that York University researchers (based on component loadings and proportion of variance explained) and FEED project staff (based on knowledge of the situation in the field) identified as potentially informing programming and interventions in South Sudan.

For elaboration, a further example is provided by PC6 in the Adaptive Resilience category (awareness of conservation, disaster, and conflict). Households that score highly on this component have (weak) tendencies to be aware of potential disasters and conflicts, and to report undertaking environmentally beneficial household practices (not burning charcoal, planting trees). Households that score weakly on this component have a moderate tendency not to report poor farming practices as contributing to environmental destruction. This PC may point to a need for programming such as education and training of farmers on good farming practices for conservation. In this domain, the Feed project worked to build capacity in sustainable agriculture (World Vision Canada et al. 2018), reaching 109,316 individuals with extension services and provision of agricultural inputs, training 837 agricultural extension workers, and 24,469 farmers in appropriate sustainable agricultural practices and techniques. Some 16,060 people were trained to respond to natural shocks, and 21,247 were trained in sustainable management of natural resources. FEED also formed or strengthened 28 community disaster risk management committees and 51 peace committees, including training 2764 participants (2038 female, 726 male) in peace promotion and conflict resolution.

Similarly, building community-level social capital is another programming opportunity indicated by these results (PC2 Transformative). Households that score highly on this PC are those in which males and females participate in common interest groups (such as farmers groups, cooperatives, market, horticultural, or traders' groups, or local NGOs), and which have access to financial institutions, land, and agricultural inputs. A 
Table 5. The five least and most resilient payams in three resilience categories; Fortifying Equality and Economic Diversification (FEED) Project, South Sudan dataset, $20155^{\dagger}$ A payam is a subcounty unit of at least 25,000 population.

\begin{tabular}{|c|c|c|c|c|c|}
\hline \multicolumn{2}{|c|}{ Absorptive } & \multicolumn{2}{|c|}{ Adaptive } & \multicolumn{2}{|c|}{ Transformative } \\
\hline Payam & z-score & Payam & z-score & Payam & z-score \\
\hline \multicolumn{6}{|c|}{ Least Resilient Payams } \\
\hline Ngapathian & -0.9 & Natabu & -0.59 & Yambio town payam & -1.13 \\
\hline Ifoto & -0.88 & Bagari & -0.46 & Akon South & -1.08 \\
\hline Wanhalel & -0.78 & Mboro & -0.42 & Thiet & -1.06 \\
\hline Thiet & -0.72 & Domoloto & -0.28 & Lukluk payam & -1.03 \\
\hline Mboro & -0.66 & Wulu & -0.26 & Wanhalel & -0.88 \\
\hline \multicolumn{6}{|c|}{ Most Resilient Payams } \\
\hline Mupoi & 0.70 & Ifwotu & 0.41 & Fodofodo & 0.61 \\
\hline Mangburu & 0.76 & Bangasu & 0.55 & Kurmalank & 0.7 \\
\hline Ri Rangu & 0.83 & Yambio town payam & 0.63 & Moti & 0.77 \\
\hline Hikpiro & 1.03 & Hikpiro & 0.76 & Ifoto & 1.04 \\
\hline Lobonok & 1.15 & Fodofodo & 1.15 & Hikpiro & 2.01 \\
\hline
\end{tabular}

${ }^{\top}$ Scores presented are standard scores or z-scores. These are based on the normal distribution such that a value of 0 is the mean, 1 is one standard deviation from the mean, etc.

Table 6. The 10 least and most resilient bomas (villages) in three resilience categories; Fortifying Equality and Economic Diversification (FEED) Project, South Sudan dataset, $2015 .^{\dagger}$

\begin{tabular}{|c|c|c|c|c|c|}
\hline \multicolumn{2}{|c|}{ Absorptive } & \multicolumn{2}{|c|}{ Adaptive } & \multicolumn{2}{|c|}{ Transformative } \\
\hline Boma & z-score & Boma & z-score & Boma & z-score \\
\hline \multicolumn{6}{|c|}{ Least Resilient Bomas (Villages) } \\
\hline Genajamo & -1.98 & Civicon & -0.73 & Hawaimeser & -2.46 \\
\hline Hawaimeser & -1.44 & Mabior-yar & -0.59 & Akon & -1.08 \\
\hline Gaai & -0.90 & Remirzer & -0.49 & Genajamo & -1.06 \\
\hline Mabior-yar & -0.78 & Natabu & -0.48 & Kit 4 & -1.04 \\
\hline Iyodo & -0.76 & Gaai & -0.42 & Mabior-yar & -0.88 \\
\hline Majookawaan & -0.47 & Iyodo & -0.31 & Moti & -0.80 \\
\hline Ngapathian & -0.45 & Domanjo & -0.27 & Umere & -0.68 \\
\hline Warkou & -0.37 & Warkou & -0.26 & Gaai & -0.64 \\
\hline Ilangi & -0.32 & Hawaimeser & -0.26 & Nabiapai & -0.53 \\
\hline Moti & -0.28 & Zangia & -0.25 & Ngapathian & -0.53 \\
\hline \multicolumn{6}{|c|}{ Most Resilient Bomas (Villages) } \\
\hline Domanjo & 0.57 & Hai korton & 0.30 & Gunyoro & 0.56 \\
\hline Asanza & 0.59 & Ilpotpot & 0.32 & Domanjo & 0.65 \\
\hline Akon & 0.64 & Akon & 0.33 & Ifotu & 0.66 \\
\hline Kit 1 & 0.80 & Iyodo & 0.39 & Somba & 0.69 \\
\hline Hikpiro & 1.03 & Lohila & 0.46 & Kohrmalang & 0.70 \\
\hline Mupoi center & 1.10 & Moti & 0.47 & Rumaluel & 0.83 \\
\hline Banzua & 1.37 & Rimenze & 0.55 & Goligo & 1.26 \\
\hline Nambia Center & 1.62 & Hikpiro & 0.76 & Mupoi center & 1.34 \\
\hline Lohila & 2.00 & Angui & 0.81 & Nambia Center & 1.49 \\
\hline Kit 4 & 2.57 & Mangburu & 0.86 & Hikpiro & 2.01 \\
\hline
\end{tabular}

${ }^{\top}$ Scores presented are standard scores or z-scores. These are based on the normal distribution such that a value of 0 is the mean, 1 is one standard deviation from the mean, etc.

large number of interventions undertaken by FEED worked to build social capital, including establishing 633 farmer field schools, the training of 136 community volunteers for, and participation of 5462 community members in, food preparation demonstrations, the formation of 77 producer and marketing groups, the afore-mentioned peace committees, disaster risk management committees, and more (World Vision Canada et al. 2018).

Another example is also seen in the Transformative Resilience category, PC3 (agricultural success and access to financial institutions), which draws out an association between high prices/ returns in agriculture and access to self-selected village savings and loans groups (self-help groups), or bank loans. This gives additional justification to FEED project interventions which were already being implemented in this area. Results from the FEED project report improved access to self-selected financial services (village savings and loans, microfinancing and formal banking), with increases from $2.9 \%$ to $39.9 \%$ of males and from $3 \%$ to $33.1 \%$ of females accessing such services from the beginning to the end of the project. At the same time, the project had some limited success in promoting access for farmers to formal financial services, being hampered by the closure of many banks in the region, high inflation rates and the devaluing of the South Sudanese currency. The FEED coalition (World Vision Canada et al. 2018) reported that some 505 farmers (33\% of the target) were linked to formal financial services, primarily through the formation of a farmers' marketing association. 
Table 7. Principal components (PC) retained in the absorptive, adaptive, and transformative resilience categories.

\begin{tabular}{|c|c|c|c|}
\hline $\mathrm{PC}$ & Absorptive resilience & Adaptive resilience & Transformative resilience \\
\hline$\overline{1}$ & $\begin{array}{l}\text { Avoidance of negative coping strategies in times } \\
\text { of food scarcity }\end{array}$ & Organized disaster management & Gender and women's empowerment \\
\hline 2 & Daily access and consumption of nutritious food & Disaster management (not organized) & Community-level social capital \\
\hline 3 & Monthly food security & $\begin{array}{l}\text { "Other" environmental conservation and } \\
\text { farming }\end{array}$ & $\begin{array}{l}\text { Agricultural success and access to financial } \\
\text { institutions }\end{array}$ \\
\hline 4 & Absence of conflict, and household assets & $\begin{array}{l}\text { "Other" environmental conservation and } \\
\text { charcoal burning }\end{array}$ & Gender Awareness \\
\hline 5 & Precarious food security & High education and income & Absence of gender-based violence \\
\hline 6 & Moderate food security and household assets & $\begin{array}{l}\text { Awareness of conservation, disaster, and } \\
\text { conflict }\end{array}$ & Access to financial services \\
\hline 7 & Families with absence of conflict & Stable income and education & Access to land for cultivation \\
\hline 8 & Precarious food security, assets, and land & Secure Income & Gender and equal opportunity \\
\hline 9 & Self-sufficiency of food & & $\begin{array}{l}\text { Women's empowerment and access to farming } \\
\text { inputs }\end{array}$ \\
\hline 10 & Good prenatal nutrition & & \\
\hline 11 & Prenatal food scarcity & & \\
\hline
\end{tabular}

Table 8. Principal components analysis (PCA) results that inform programming and intervention (South Sudan 2015 Dataset).

\begin{tabular}{|c|c|c|}
\hline Principal Component & PC Label & Programming implications \\
\hline Absorptive PC1 & $\begin{array}{l}\text { Avoidance of negative coping } \\
\text { strategies }\end{array}$ & $\begin{array}{l}\text { Strengthen capacities for positive coping strategies to food scarcity, e.g., grain } \\
\text { storage facilities. Educate about the risks of negative coping strategies, such as } \\
\text { harvesting immature crops }\end{array}$ \\
\hline Absorptive PC4 & $\begin{array}{l}\text { Absence of conflict, and household } \\
\text { assets }\end{array}$ & $\begin{array}{l}\text { Strengthen community-scale capacity to avoid or mitigate conflict, such as } \\
\text { establishing "peace committees" }\end{array}$ \\
\hline Adaptive PC1 & Organized disaster management & $\begin{array}{l}\text { Strengthen capacity at the community level for disaster management, e.g., } \\
\text { establish disaster management committees }\end{array}$ \\
\hline Adaptive PC2 & $\begin{array}{l}\text { Disaster management (not } \\
\text { organized) }\end{array}$ & $\begin{array}{l}\text { Strengthen household disaster management capacity, e.g., awareness of beneficial } \\
\text { and harmful agricultural practices, and conservation practices }\end{array}$ \\
\hline Adaptive PC5 & High education and income & $\begin{array}{l}\text { Strengthen awareness and capacity for good farming practices with respect to } \\
\text { conservation (a factor with negative association with this PC) }\end{array}$ \\
\hline Adaptive PC6 & $\begin{array}{l}\text { Awareness of conservation, } \\
\text { disaster, and conflict }\end{array}$ & $\begin{array}{l}\text { Strengthen awareness and capacity for good farming practices with respect to } \\
\text { conservation (a factor with negative association with this PC) }\end{array}$ \\
\hline Adaptive PC7 & Stable income and education & Develop capacity in income generating activities \\
\hline Adaptive PC8 & Secure income & Develop capacity in income generating activities \\
\hline Transformative PC1 & $\begin{array}{l}\text { Gender and women's } \\
\text { empowerment }\end{array}$ & Undertake gender equality programming \\
\hline Transformative PC2 & Community-level social capital & $\begin{array}{l}\text { Foster community capacity in common interest groups such as farmers' groups, } \\
\text { cooperatives, traders' groups, and local NGOs }\end{array}$ \\
\hline Transformative PC3 & $\begin{array}{l}\text { Agricultural success and access to } \\
\text { financial institutions }\end{array}$ & $\begin{array}{l}\text { Develop capacity for access to financial institutions such as bank loans and self- } \\
\text { help groups. }\end{array}$ \\
\hline
\end{tabular}

Because the FEED project proposal (with goals and programming as developed) was already approved and funded, and field work was ongoing when the dataset that is the subject of this paper was collected and analyzed, the results presented here serve to reinforce many of the programming decisions and interventions of the FEED project, rather than leading to decisions to undertake them in the first place. A second phase of the project, however, has recently begun: FEED II. Here there is an opportunity to underpin this next phase of the project, in concert with the other experiences and results of FEED. This is especially evident in the area of gender equality and gender-based violence, which has a much-increased emphasis in FEED II. Even in FEED, when additional resources became available because of a positive exchange rate, this is the area where they were allocated, which is why FEED was able to exceed their target to enhance women's asset ownership and management by $228 \%$, and to train 24,027 female and 25,098 male participants in gender-based violence prevention and response (World Vision Canada et al.
2018). Such attention to GBV and gender equality corresponds with the implications of PC1 in the Transformative Resilience category: gender and women's empowerment.

\section{Measuring and assessing resilience}

It should be noted that, as employed in this paper, the quantitative approach involving analyses of survey data using PCA, required some simplifications in order to accommodate measurement issues and the collection of data suitable for quantitative analysis. Quinlan et al. (2016), in their discussion of measuring and assessing resilience, make the point that the simplification involved in quantifying resilience does not necessarily detract from understanding situations more systemically. They contrast resilience measurement (for quantitative analysis) with resilience assessment, which tends to be more qualitative and participatory in nature, and oriented to understanding system dynamics in such a way as to guide "the development of a conceptual model of an integrated social-ecological system where key actors, ecological structure and their interactions are identified in relation to the 
larger context in which they are embedded" (Quinlan et al. 2016:679). They further recommend that where resilience measurement is undertaken, it be part of a hybrid approach that also involves resilience assessment. In short, they contend that mixed methods research designs could prove to be useful in resilience analysis.

Although this paper focuses on an approach that quantifies resilience, this was also part of a wider assessment process. In particular, it improved on an earlier resilience context analysis carried out by a partnership of international agencies (WFP 2015). WFP and their partners attempted to understand those characteristics and relationships in South Sudan related to livelihoods, land cover, agricultural production, population changes, incidence of conflict, precipitation, flood and drought risk, access to services, infrastructure, markets, prevalence of food insecurity, and the policy environment. The approach was both qualitative and quantitative, involving a review of relevant literature, an analysis of secondary data, consultations with agencies and stakeholders, and a workshop with participants from the national government, development agencies, and representatives who provided community experiences and perspectives.

This approach resulted in the conceptual model of the socialecological system in South Sudan and informed further quantitative work by identifying shocks and stressors and elaborating on the absorptive, adaptive, and transformative resilience capabilities described above. The FEED project furthered this approach in their programming and intervention, focusing, confirming, and tailoring this model with further literature reviews, nine focus groups, and three key informant interview discussions, involving 21 women and 52 men who were purposively sampled on the basis of their role in agriculture in the targeted communities.

In a hybrid or mixed methods approach, this resilience assessment should inform resilience measurement with an understanding of context, system dynamics, relevant (multiple) scales, and relationships. For example, systems approaches such as resilience thinking typically address at least three levels of systems: the systems of interest and one level down (subsystems) and one level up (the supersystem or environment; Flood and Carson 1998). Although not explicitly identified, the survey administered in South Sudan was defined by four levels: individual, household, community (boma and payam), and regional/national (county and state scales). Although there are several issues involved in the design and application of a multilevel hierarchical study such as the FEED project, some of the more important weaknesses appeared to be at the lowest and highest levels in the South Sudan case.

At the individual level, the survey asked questions primarily in relation to gender equality and gender-based violence: for example, "In which of the following areas did you participate in the decision making over the last 12 months: Which crops to grow?; What and when to sell (crop/livestock)?; How to use proceeds from the sale of crops/livestock?; When to conceive/become pregnant/number of children?" Most questions were oriented to the household level, e.g., "Have you or any member of your household been trained on proper feeding or balanced diet for all household members?" and at the community level, e.g., "Do you have any conflicts within your community?"; "Does this community have a disaster management committee?" There are several important assumptions made in such questioning, principally that the closer (to life experiences) the question is, the more valid the response, compared to questions that relate to a broader entity such as a community, or in some cases even the household.

At the supersystems level, the survey attempted to capture household exposure to higher level policy and driving forces by including questions about access to and participation in agricultural extension programs, access to financial institutions, and exposure to conflict. But the FEED survey had limited linkages between households and communities and their environmental (ecological) context. Given the interconnectedness between agricultural production and ecological context, greater emphasis should have been placed on linking ecological and social dynamics. Thus, while the survey did include questions pertaining to access to land, animal husbandry, access to agricultural extension, and agricultural inputs, it did not illuminate such factors as the flow or distribution of ecological goods and services and perceptions of agro-ecosystem health. These are design issues.

This discussion relates to our confidence in the results presented at the various scale levels; state/county, payam/boma, household, and individual. Because fewer of the FEED survey questions were oriented to the higher supersystem level (especially those items relating to ecological context) compared to household and community levels (including the village clusters or payams), we suggest that the results of our analysis are most dependable (or at least, those findings in which we have the most confidence) at the household and community levels, and least so at the state level. Even at the level of household or community, however, where we are most confident, it is important to note that not everyone in that system or group will benefit universally or to an equal extent. In light of the women's empowerment agenda in both the FEED and FEED II projects, it would be important to explore the different vulnerabilities and resilience capacities associated with women and men. Questions pertaining to, for example, differences among households with female- versus male-headed households, would be most usefully explored in future work.

Finally, we should note that complementary investigations into agro-ecosystem health and landscape ecology could, and perhaps should, given the environmental context, supplement this aspect of resilience assessment. Among the tools that might prove useful to incorporate in this dimension, the Resilience Alliance's workbook (Resilience Alliance 2010), which emphasizes the relationships between ecological and social systems, should be evaluated. The FEED team is responding to this deficit: the FEED II baseline information will incorporate more environmental data, increased attention to agricultural zones, and greater environmental analysis and programming, including community mapping, early warning, and early action plans.

\section{CONCLUSIONS}

The approach to quantifying resilience that we have demonstrated in this paper is both possible and useful. Principal components analysis is a common statistical data-analytic tool that can be carried out by any competent quantitative researcher. It reduces dimensionality in the input dataset and can identify underlying latent variables that are not directly measured. PCA provides a means to "stay close" to the data, and it produces index measures 
or component scores, as in this case, that can indicate resilience at the level of households and above. This supports the targeting of households and communities most in need of program interventions to strengthen resilience. It also supports the identification of programming to do so. For example, this work identified several programming interventions (Table 8), some of which FEED was already employing, such as strengthening capacities for positive coping strategies to food scarcity, e.g., grain storage facilities, and strengthening community-scale capacity to avoid or mitigate conflict, e.g., establishing peace committees.

On the other hand, because of the very difficult on-the-ground conditions in South Sudan, the data employed in this work were problematic. If quantitative analysis is desired for such data, then future household surveys should be designed with quantitative analysis in mind, ideally with knowledge of the method intended and its requirements. In particular, survey questions should be designed to avoid null or no responses. Such responses can drastically reduce the number of valid cases or necessitate the removal of variables from the analysis. Similarly, survey designers should avoid asking questions to only some survey respondents, e.g., women only, or men only, unless this is part of the sample design (in which case the effects can be weighted statistically postsurvey). Finally, if methods requiring independent variables are intended, e.g., regression analysis, it should be ensured that these independent variables are part of the survey, or otherwise available. As with the point above, this would need to be part of the research design, i.e., a model-based design that starts with an intended model (such as regression) and then identifies what is/ are the dependent variable(s), what is/are the independent variable (s), etc. Other improvements to this approach would include the incorporation of variables describing households' and communities' connection to their ecological context (such as indicators of agro-ecosystem health).

We concur with Quinlan et al. (2016) who recommend that when measurement of resilience is undertaken, this should be part of the larger effort of resilience assessment that informs a conceptual model (typically) of a social-ecological system that guides the quantitative research design, measurement, and analysis. In the case of the FEED project, such an assessment was provided by earlier work in the form of a resilience context analysis (WFP 2015), as well as supplementary key informant interviews, focus groups, and baseline and gender assessments (Wasaga 2015a, b), at the beginning of the project. The quantitative analysis, employing PCA, thus produced results that identified meaningful aspects of the situation, i.e., the latent variables, that illuminated relevant implications for project programming and intervention. Among such direct effects, we note that the first principal component (PC1) in the absorptive category pointed to the avoidance of negative coping strategies, which has programming implications to strengthen capacity for positive coping strategies to food scarcity, and education about the risks of negative coping strategies such as harvesting immature crops. Similarly, PC1 in the adaptive category identified organized disaster management, which underlines the importance of strengthening capacity at the community level for disaster management, e.g., establishing disaster management committees, and again in PC1 (Transformative) which highlighted gender and women's empowerment. This finding reinforced the work of FEED on gender equality programming and gender-based violence, which is further strengthened in FEED II.
Overall, this approach to quantifying resilience in households and communities in a development context, produced results that, even with some problematic data issues, proved useful and insightful. Considering the fact that the resilience approach is accepted and employed in international development practice, further development of this approach and demonstration of its methodology may have impacts beyond the current project. Finally, the focus of studies such as that reported here, at the community and household level, is pragmatic and beneficial, enabling the collection of relevant data directly from those households that are intended to be beneficiaries of the project.

\section{Responses to this article can be read online at: http://www.ecologyandsociety.org/issues/responses. php/11450}

\section{Acknowledgments:}

The authors would like to express their thanks to Vincent Wanyama, Consultant to World Vision International, and Hailu Tolasa, Chief of Party, FEED Project, World Vision South Sudan, for consultation on the field conditions and data collection for the project. We would also like to recognize the contributions of anonymous reviewers, whose insightful critique and comments helped to improve this manuscript.

\section{LITERATURE CITED}

Abdi, H., and L. J. Williams. 2010. Principal component analysis. Wiley Interdisciplinary Reviews: Computational Statistics 2 (4):433-459. https://doi.org/10.1002/wics.101

Alinovi, L., E. Mane, and D. Romano. 2008. Towards the measurement of household resilience to food insecurity: applying a model to Palestinian household data. Pages 137-152 in E. Sibrian, editor. Deriving food security information from national household budget surveys: experiences, achievement, challenges. Food and Agriculture Organization, Rome, Italy.

Ashdown, P. 2011. Humanitarian emergency response review. Department for International Development, London, UK.

Barrett, C. B., and M. A. Constas. 2014. Toward a theory of resilience for international development applications. Proceedings of the National Academy of Sciences 111(40):14625-14630. https:// doi.org/10.1073/pnas.1320880111

Béné, C., T. Frankenberger, and S. Nelson. 2015. Design, monitoring and evaluation of resilience interventions: conceptual and empirical considerations. Institute of Development Studies, London, UK.

Berkes, F., J. Colding, and C. Folke. 2003. Navigating socialecological systems: building resilience for complexity and change. Cambridge University Press, Cambridge, UK. https://doi. org/10.1017/CBO9780511541957

Berkes, F., and H. Ross. 2013. Community resilience: toward an integrated approach. Society \& Natural Resources 26(1):5-20. https://doi.org/10.1080/08941920.2012.736605 
Carpenter, S., B. Walker, J. M. Anderies, and N. Abel. 2001. From metaphor to measurement: resilience of what to what? Ecosystems 4:765-781. https://doi.org/10.1007/s10021-001-0045-9

Cliff, N. 1987. Analyzing multivariate data. Harcourt Brace Jovanovich, Toronto, Ontario, Canada.

Community and Regional Resilience Institute (CARRI). 2013. Definitions of community resilience: an analysis. CARRI, Washington, D.C., USA.

Constas, M. A., T. R. Frankenberger, and J. Hoddinott. $2014 b$. Resilience measurement principles: toward an agenda for measurement design. Food Security Information Network, Food and Agriculture Organization, and World Food Programme, Rome, Italy.

Constas, M. A., T. R. Frankenberger, J. Hoddinott, N. Mock, D. Romano, C. Béné, and D. Maxwell. 2014a. A common analytical model for resilience measurement: causal framework and methodological options. Food Security Information Network, Food and Agriculture Organization, and World Food Programme, Rome, Italy.

Flood, R. L., and E. R. Carson. 1998. Dealing with complexity: an introduction to the theory and application of systems science. Plenum Press, New York, New York, USA.

Folke, C. 2016. Resilience (Republished). Ecology and Society 21 (4). https://doi.org/10.5751/ES-09088-210444

Folkema, J., M. Ibrahim, and E. Wilkinson. 2013. World Vision's resilience programming: adding value to development. Overseas Development Institute, London, UK.

Groth, D., S. Hartmann, S. Klie, and J. Selbig. 2013. Principal components analysis. Pages 527-547 in B. Reisfeld and A. N. Mayeno, editors. Computational toxicology. Humana, Totowa, New Jersey, USA. https://doi.org/10.1007/978-1-62703-059-5 22

Gunderson, L., and C. S. Holling, editors. 2002. Panarchy: understanding transformations in human and natural systems. Island, Washington, D.C., USA.

Holling, C. S. 1973. Resilience and stability of ecological systems. Annual Review of Ecology and Systematics 4:1-23. https://doi. org/10.1146/annurev.es.04.110173.000245

Holling, C. S. 1996. Engineering resilience versus ecological resilience. Pages 31-43 in P. C. Schulze, editor. Engineering within ecological constraints. National Academies, Washington, D.C., USA.

Johnson, R. A., and D. W. Wichern. 1992. Applied multivariate statistical analysis. Prentice-Hall Canada Inc., Toronto, Ontario, Canada.

Kulig, J. C., D. S. Edge, I. Townshend, N. Lightfoot, and W. Reimer. 2013. Community resiliency: emerging theoretical insights. Journal of Community Psychology 41(6):758-775. https:// doi.org/10.1002/jcop. 21569

Lindeman, R. H., P. F. Merenda, and R. Z. Gold. 1980. Introduction to bivariate and multivariate analysis. Scott, Foresman and Company, London, UK.
Maclean, K., M. Cuthill, and H. Ross. 2014. Six attributes of social resilience. Journal of Environmental Planning and Management 57(1):144-156. https://doi.org/10.1080/09640568.2013.763774

Mayne, J. 2015. Useful theory of change models. Canadian Journal of Program Evaluation 30(2):119-142.

Norris, F. H., S. P. Stevens, B. Pfefferbaum, K. F. Wyche, and R. L. Pfefferbaum. 2008. Community resilience as a metaphor, theory, set of capacities, and strategy for disaster readiness. American Journal of Community Psychology 41(1-2):127-150. https://doi.org/10.1007/s10464-007-9156-6

Olsson, L., A. Jerneck, H. Thoren, J. Persson, and D. O'Byrne. 2015. Why resilience is unappealing to social science: theoretical and empirical investigations of the scientific use of resilience. Science Advances 1(4):e1400217. https://doi.org/10.1126/sciadv.1400217

Papavero, C., E. Reidy, G. Polidori, and S. Regi. 2015. Resilience context analysis: resilience to shocks that impact food insecurity and nutrition in South Sudan (Second Draft). United Nations Office at Nairobi, Juba, South Sudan.

Perrings, C. 1998. Introduction: resilience and sustainability. Environment and Development Economics 3(2):221-262. https:// doi.org/10.1017/S1355770X98210126

Quinlan, A. E., M. Berbés-Blázquez, L. J. Haider, and G. D. Peterson. 2016. Measuring and assessing resilience: broadening understanding through multiple disciplinary perspectives. Journal of Applied Ecology 53(3):677-687. https://doi.org/10.1111/1365-2664.12550

Resilience Alliance. 2010. Assessing resilience in social-ecological systems: workbook for practitioners. Version 2.0. [online] URL: https://www.resalliance.org/resilience-assessment

United Nations Office for the Coordination of Humanitarian Affairs. 2018. 2019 Humanitarian needs overview: South Sudan. United Nations Office for the Coordination of Humanitarian Affairs, Juba, South Sudan.

Wasaga, R. 2015a. Exit report for FEED Project baseline and gender assessment. Kenwell International Limited, Kampala, Uganda.

Wasaga, R. 2015b. Fortifying equality and economic diversification - improved livelihoods in South Sudan: baseline survey report. Kenwell International Limited, Kampala, Uganda.

World Food Programme (WFP). 2015. Resilience context analysis: resilience to shocks that impact food security and nutrition in South Sudan. United Nations World Food Programme, Nairobi, Kenya.

World Vision Canada, Oxfam Canada, and CARE Canada. 2018. Fortifying equality and economic diversification: improved livelihoods in South Sudan final report. Foreign Affairs, Trade and Development Canada, Ottawa, Ontario, Canada. 
Appendix 1: Principal component descriptions and variable loadings

\author{
ABSORBTIVE RESILIENCE \\ Identification of Principal Components \\ The Absorptive Resilience dataset that was prepared for Principal Components Analysis \\ consisted of 44 variables and 817 records. Eleven components were retained and described as \\ latent variables, explaining $63.1 \%$ of variance in the dataset: \\ - Component 1: Avoidance of Negative Coping Strategies in Times of Food Scarcity \\ - Component 2: Daily Access and Consumption of Nutritious Food \\ - Component 3: Monthly Food Security \\ - Component 4: Absence of Conflict, and Household Assets \\ - Component 5: Precarious Food Security \\ - Component 6: Moderate Food Security, and Household Assets \\ - Component 7: Families with Absence of Conflict \\ - Component 8: Precarious Food Security, Assets and Land \\ - Component 9: Self-sufficiency of Food \\ - Component 10: Good Prenatal Nutrition \\ - Component 11: Prenatal Food Scarcity
}

\title{
Absorptive Resilience Principal Component 1: Avoidance of Negative Coping Strategies in Times of Food Scarcity
}

Households that score highly on this PC are those that avoid negative coping strategies in times of food scarcity. Households that score low on this PC do not use (or perhaps do not have access to) positive coping strategies. Such results can be used to identify households that are less or more resilient in terms of coping strategies in times of food scarcity. But this component also points to targets for programming and validates some of the work done by World Vision since the 2015 survey was undertaken. For example, in November of 2017 one project beneficiary stated, "We no longer fear July," which in the past has been a month of scarcity. This is due to work to reinforce, and to make possible, positive coping strategies. For example, World Vision staff trained project participants to build storage facilities that are resistant to pests, rain and dampness, providing for both stores of food to draw upon in lean seasons, and to sell at market to generate income. Building social capital is another programming opportunity indicated by these results, as drawing upon social networks to feed household members is a better coping strategy than, e.g., selling liquid assets, harvesting immature crops or simply going hungry. 
Appendix 1: Principal component descriptions and variable loadings

Table 1.1: Variance explained for Absorptive Resilience PC1

\begin{tabular}{|l|l|l|l|}
\hline Component & Initial Eigenvalues & \multicolumn{2}{|l|}{ Extraction Sums of Squared Loadings } \\
\hline & Total & $\%$ of Variance & Cumulative \% \\
\hline 1 & 7.453 & 16.939 & 16.939 \\
\hline
\end{tabular}

Table 1.2: Variables defining Absorptive Resilience PC1

\begin{tabular}{|c|c|c|}
\hline Variable & $\begin{array}{l}\text { Component } \\
\text { Loading }\end{array}$ & Survey Questions \\
\hline$q 2512$ & 0.707 & $\begin{array}{l}\text { Q } 2.5 \text { In the past } 30 \text { days, how frequently did your household use } \\
\text { the following strategies in order to access food?; } 2.5 .12 \text { Restrict } \\
\text { consumption by adults so children can eat more? }\end{array}$ \\
\hline q2511 & 0.703 & $\begin{array}{l}\text { Q } 2.5 \text { In the past } 30 \text { days, how frequently did your household use } \\
\text { the following strategies in order to access food?; } 2.5 .11 \text { Send } \\
\text { household members to beg? }\end{array}$ \\
\hline $\mathrm{q} 254$ & -0.692 & $\begin{array}{l}\text { Q } 2.5 \text { In the past } 30 \text { days, how frequently did your household use } \\
\text { the following strategies in order to access food?; } 2.5 .4 \text { Borrow food } \\
\text { or rely on help from a friend or relative? }\end{array}$ \\
\hline $\mathrm{q} 2510$ & -0.692 & $\begin{array}{l}\text { Q } 2.5 \text { In the past } 30 \text { days, how frequently did your household use } \\
\text { the following strategies in order to access food?; } 2.5 .10 \text { Send } \\
\text { household members to eat elsewhere? }\end{array}$ \\
\hline q259 & 0.681 & $\begin{array}{l}\text { Q } 2.5 \text { In the past } 30 \text { days, how frequently did your household use } \\
\text { the following strategies in order to access food?; } 2.5 .9 \text { Harvest } \\
\text { immature crops (e.g. green mealies)? }\end{array}$ \\
\hline q256 & 0.663 & $\begin{array}{l}2.5 \text { In the past } 30 \text { days, how frequently did your household use the } \\
\text { following strategies in order to access food?; } 2.5 .6 \text { Purchase food } \\
\text { on credit, or take a loan to purchase food? }\end{array}$ \\
\hline $\mathrm{q} 258$ & -0.644 & $\begin{array}{l}\text { Q 2.5 In the past } 30 \text { days, how frequently did your household use } \\
\text { the following strategies in order to access food?; } 2.5 .8 \text { Gather } \\
\text { unusual types/amounts of wild food or hunt? }\end{array}$ \\
\hline
\end{tabular}


Appendix 1: Principal component descriptions and variable loadings

\begin{tabular}{|c|c|c|}
\hline Variable & $\begin{array}{l}\text { Component } \\
\text { Loading }\end{array}$ & Survey Questions \\
\hline q2514 & 0.632 & $\begin{array}{l}\text { Q } 2.5 \text { In the past } 30 \text { days, how frequently did your household use } \\
\text { the following strategies in order to access food?; } 2.5 .14 \text { Sale of } \\
\text { liquid assets e.g. Goats, sheep, pigs, etc. Mattress, bicycles }\end{array}$ \\
\hline $\mathrm{q} 253$ & 0.617 & $\begin{array}{l}\text { Q } 2.5 \text { In the past } 30 \text { days, how frequently did your household use } \\
\text { the following strategies in order to access food?; } 2.5 .3 \text { Skip entire } \\
\text { days without eating? }\end{array}$ \\
\hline q2515 & 0.605 & $\begin{array}{l}\text { Q 2.5 In the past } 30 \text { days, how frequently did your household use } \\
\text { the following strategies in order to access food?; } 2.5 .15 \text { Sale of } \\
\text { productive assets e.g. seeds, land, large animals }\end{array}$ \\
\hline q2513 & -0.576 & $\begin{array}{l}\text { Q } 2.5 \text { In the past } 30 \text { days, how frequently did your household use } \\
\text { the following strategies in order to access food?; } 2.5 .13 \text { Rely on } \\
\text { casual labour for food? }\end{array}$ \\
\hline $\mathrm{q} 252$ & 0.546 & $\begin{array}{l}\text { Q 2.5 In the past } 30 \text { days, how frequently did your household use } \\
\text { the following strategies in order to access food?; } 2.5 .2 \text { Reduce } \\
\text { number of meals eaten per day? }\end{array}$ \\
\hline $\mathrm{q} 255$ & -0.523 & $\begin{array}{l}\text { Q } 2.5 \text { In the past } 30 \text { days, how frequently did your household use } \\
\text { the following strategies in order to access food?; } 2.5 .5 \text { Rely on less } \\
\text { expensive or less preferred foods? }\end{array}$ \\
\hline $\mathrm{q} 251$ & 0.515 & $\begin{array}{l}\text { Q } 2.5 \text { In the past } 30 \text { days, how frequently did your household use } \\
\text { the following strategies in order to access food?; } 2.5 .1 \text { Limit } \\
\text { portion size at meal times? }\end{array}$ \\
\hline $\begin{array}{l}\mathrm{q} 233 \_23 \\
4\end{array}$ & 0.429 & $\begin{array}{l}\text { Q 2.3.3 In the past four weeks did anyone in your household go to } \\
\text { sleep hungry?; Q 2.3.4 How often did this happen? }\end{array}$ \\
\hline $\begin{array}{l}q 235 \_23 \\
6\end{array}$ & 0.415 & $\begin{array}{l}\text { Q 2.3.5 Did anyone go without food for a full day in the past } \\
\text { month?; Q 2.3.6 How often did this happen? }\end{array}$ \\
\hline q231_23 & 0.406 & $\begin{array}{l}\text { Q 2.3.1 In the past } 4 \text { weeks, were there no food?; Q 2.3.2 How } \\
\text { often did this happen? }\end{array}$ \\
\hline $\mathrm{q} 257$ & -0.380 & $\begin{array}{l}\text { Q } 2.5 \text { In the past } 30 \text { days, how frequently did your household use } \\
\text { the following strategies in order to access food?; } 2.5 .7 \text { Use food } \\
\text { from granary or store }\end{array}$ \\
\hline
\end{tabular}


Appendix 1: Principal component descriptions and variable loadings

\begin{tabular}{|l|l|l|}
\hline Variable & $\begin{array}{l}\text { Component } \\
\text { Loading }\end{array}$ & Survey Questions \\
\hline q24411 & 0.347 & $\begin{array}{l}\text { Q 2.4.4 Now I would like to ask you about the types of foods that } \\
\text { you or anyone else in your household ate yesterday during the day } \\
\text { and night?; 11) Any sugar or honey? }\end{array}$ \\
\hline q24412 & 0.322 & $\begin{array}{l}\text { Q 2.4.4 Now I would like to ask you about the types of foods that } \\
\text { you or anyone else in your household ate yesterday during the day } \\
\text { and night?; 12) Any other foods such as, coffee or tea? }\end{array}$ \\
\hline q2611 & 0.301 & $\begin{array}{l}\text { Q 2.6.11 Over the past month, did anyone in the household ever go } \\
\text { without food for a whole day because there wasn't enough? }\end{array}$ \\
\hline
\end{tabular}

\section{Absorptive Resilience Principal Component 2: Daily Access and Consumption of Nutritious Food}

Households that are positively correlated to this principal component are those that report that persons in their household ate a variety of foods in the previous day, such as dairy, protein, and carbohydrates. The weakest relationship was for consumption of vegetables.

Table 1.3: Variance explained for Absorptive Resilience PC2

\begin{tabular}{|l|l|l|l|}
\hline Component & Initial Eigenvalues & \multicolumn{2}{|c|}{ Extraction Sums of Squared Loadings } \\
\hline & Total & \% of Variance & Cumulative \% \\
\hline 2 & 6.194 & 14.078 & 31.017 \\
\hline
\end{tabular}

Table 1.4: Variables defining Absorptive Resilience PC2

\begin{tabular}{|l|l|l|}
\hline Variable & $\begin{array}{l}\text { Component } \\
\text { Loading }\end{array}$ & Survey Questions \\
\hline q2449 & 0.785 & $\begin{array}{l}\text { Q 2.4.4 Now I would like to ask you about the types of foods } \\
\text { that you or anyone else in your household ate yesterday during } \\
\text { the day and night?; 9) Any cheese, yogurt, milk or other milk } \\
\text { product? }\end{array}$ \\
\hline q2446 & 0.774 & $\begin{array}{l}\text { Q 2.4.4 Now I would like to ask you about the types of foods } \\
\text { that you or anyone else in your household ate yesterday during } \\
\text { the day and night?; 6) Any eggs? }\end{array}$ \\
\hline
\end{tabular}


Appendix 1: Principal component descriptions and variable loadings

\begin{tabular}{|c|c|c|}
\hline Variable & $\begin{array}{l}\text { Component } \\
\text { Loading }\end{array}$ & Survey Questions \\
\hline q2448 & 0.771 & $\begin{array}{l}\text { Q 2.4.4 Now I would like to ask you about the types of foods } \\
\text { that you or anyone else in your household ate yesterday during } \\
\text { the day and night?; 8) Any food made from beans, peas, nuts? }\end{array}$ \\
\hline q24410 & 0.767 & $\begin{array}{l}\text { Q 2.4.4 Now I would like to ask you about the types of foods } \\
\text { that you or anyone else in your household ate yesterday during } \\
\text { the day and night?; 10) Any foods made with oil, fat or butter? }\end{array}$ \\
\hline q2447 & 0.753 & $\begin{array}{l}\text { Q 2.4.4 Now I would like to ask you about the types of foods } \\
\text { that you or anyone else in your household ate yesterday during } \\
\text { the day and night?; 7) Any fresh or dried fish? }\end{array}$ \\
\hline q2445 & 0.739 & $\begin{array}{l}\text { Q 2.4.4 Now I would like to ask you about the types of foods } \\
\text { that you or anyone else in your household ate yesterday during } \\
\text { the day and night?; 5) Any beef, pork, lamb goat, rabbit, } \\
\text { chicken, duck or other birds, liver, kidney, or other meats? }\end{array}$ \\
\hline q24412 & 0.737 & $\begin{array}{l}\text { Q 2.4.4 Now I would like to ask you about the types of foods } \\
\text { that you or anyone else in your household ate yesterday during } \\
\text { the day and night?; 12) Any other foods such as, coffee or tea? }\end{array}$ \\
\hline q24411 & 0.705 & $\begin{array}{l}\text { Q 2.4.4 Now I would like to ask you about the types of foods } \\
\text { that you or anyone else in your household ate yesterday during } \\
\text { the day and night?; 11) Any sugar or honey? }\end{array}$ \\
\hline q2444 & 0.667 & $\begin{array}{l}\text { Q 2.4.4 Now I would like to ask you about the types of foods } \\
\text { that you or anyone else in your household ate yesterday during } \\
\text { the day and night? ; 4) Any fruits? }\end{array}$ \\
\hline q2442 & 0.522 & $\begin{array}{l}\text { Q 2.4.4 Now I would like to ask you about the types of foods } \\
\text { that you or anyone else in your household ate yesterday during } \\
\text { the day and night?; 2) Any potatoes, yams, cassava or any } \\
\text { other foods made from roots or tubers? }\end{array}$ \\
\hline q2443 & 0.330 & $\begin{array}{l}\text { Q 2.4.4 Now I would like to ask you about the types of foods } \\
\text { that you or anyone else in your household ate yesterday during } \\
\text { the day and night?; 3) Any vegetables? }\end{array}$ \\
\hline
\end{tabular}


Appendix 1: Principal component descriptions and variable loadings

Absorptive Resilience Principal Component 3: Monthly Food Security

This component describes households that did not experience hunger in the last month, but had a (weak) tendency to draw upon social capital (sending household members to eat elsewhere) to access food. There is also a weak indication that these households have enough income to afford basic goods (shoes). There is a weak tendency of households scoring low on this component to sell productive assets to access food.

Table 1.5: Variance explained for Absorptive Resilience PC3

\begin{tabular}{|l|l|l|l|}
\hline Component & Initial Eigenvalues & \multicolumn{2}{|c|}{ Extraction Sums of Squared Loadings } \\
\hline & Total & $\%$ of Variance & Cumulative \% \\
\hline 3 & 2.773 & 6.303 & 37.32 \\
\hline
\end{tabular}

Table 1.6: Variables defining Absorptive Resilience PC3

\begin{tabular}{|l|l|l|}
\hline Variable & $\begin{array}{l}\text { Component } \\
\text { Loading }\end{array}$ & Survey Questions \\
\hline q233_234 & 0.676 & $\begin{array}{l}\text { Q 2.3.3 In the past four weeks did anyone in your household go to } \\
\text { sleep hungry?; 2 2.3.4 How often did this happen? }\end{array}$ \\
\hline q231_232 & 0.658 & $\begin{array}{l}\text { Q 2.3.1 In the past 4 weeks, were there no food?; Q 2.3.2 How } \\
\text { often did this happen? }\end{array}$ \\
\hline q235_236 & 0.658 & $\begin{array}{l}\text { Q 2.3.5 Did anyone go without food for a full day in the past } \\
\text { month?; Q 2.3.6 How often did this happen?; }\end{array}$ \\
\hline q2611 & 0.487 & $\begin{array}{l}\text { Q 2.6.11 Over the past month, did anyone in the household ever go } \\
\text { without food for a whole day because there wasn't enough? }\end{array}$ \\
\hline q2614 & 0.346 & $\begin{array}{l}\text { Q 2.6.14 Does every member of the household have at least one } \\
\text { pair of shoes? }\end{array}$ \\
\hline q2510 & 0.323 & $\begin{array}{l}\text { 2.5 In the past 30 days, how frequently did your household use the } \\
\text { following strategies in order to access food?; 2.5.10 Send } \\
\text { household members to eat elsewhere? }\end{array}$ \\
\hline q2515 & -0.302 & $\begin{array}{l}\text { Q 2.5 In the past 30 days, how frequently did your household use } \\
\text { the following strategies in order to access food?; 2.5.15 Sale of } \\
\text { productive assets e.g. seeds, land, large animals }\end{array}$ \\
\hline
\end{tabular}


Appendix 1: Principal component descriptions and variable loadings

Absorptive Resilience Principal Component 4: Absence of Conflict, and Household Assets Households that score high on this component tend (weakly) to have enough income/resources to have basic goods (shoes, clothes) and domestic animals. At the other end of the scale, households that score low on this component have moderate tendencies to have experienced and been affected by conflict and economic loss. It seems reasonable to speculate that these characteristics show up in this PC in this way if conflict impedes a household's ability to accumulate or retain assets such as clothes and domestic animals. Some programming in the FEED project has dealt with the situation of conflict by establishing "peace committees" in some villages. This PC implies that such programming is on the right track.

Table 1.7: Variance explained for Absorptive Resilience PC4ariance explained for Absorptive Resilience PC4

\begin{tabular}{|l|l|l|l|}
\hline Component & Initial Eigenvalues & Extraction Sums of Squared Loadings \\
\hline & Total & $\%$ of Variance & Cumulative \% \\
\hline 4 & 2.001 & 4.547 & 41.866 \\
\hline
\end{tabular}

Table 1.8: Variables defining Absorptive Resilience PC4

\begin{tabular}{|l|l|l|}
\hline Variable & $\begin{array}{l}\text { Component } \\
\text { Score }\end{array}$ & Survey Questions \\
\hline q71_q72n & -0.564 & $\begin{array}{l}\text { Q 7.1. Do you have any conflicts within your community? Q 7.2. If } \\
\text { yes, what types of conflicts are within your community? }\end{array}$ \\
\hline q74 & -0.527 & Q7.4. Is your household directly affected by above conflicts? \\
\hline q2612 & 0.417 & $\begin{array}{l}\text { Q 2.6.12 Does every member of the household have at least two sets of } \\
\text { clothes? }\end{array}$ \\
\hline q269a & -0.400 & $\begin{array}{l}\text { Q 2.6.9 In the last 12 months (mention the month) did the household } \\
\text { experience any adverse event that led to an economic loss? }\end{array}$ \\
\hline q58_all & 0.397 & Q 5.8 What nutritious supplementary infant foods do you know about? \\
\hline q2614 & 0.324 & $\begin{array}{l}\text { Q 2.6.14 Does every member of the household have at least one pair of } \\
\text { shoes? }\end{array}$ \\
\hline q43 & 0.306 & Q 4.3. Does your household own any domestic animals? \\
\hline
\end{tabular}


Appendix 1: Principal component descriptions and variable loadings

\section{Absorptive Resilience Principal Component 5: Periodic Food Scarcity}

Households that score highly on this component had a week tendency to report consuming vegetables, roots and tubers in the previous day, and to have used food stores to cope with food scarcity over the last month. Other foods such as meats and dairy are not related to this component. These households have tended (weakly) not to be affected by conflict. Households scoring low on this component have a weak to moderate tendency to indicate that children had not eaten in the previous day and that the household head was not able to provide food for family members at some point in the previous year.

Table 1.9: Variance explained for Absorptive Resilience PC5

\begin{tabular}{|l|l|l|l|}
\hline Component & Initial Eigenvalues & Extraction Sums of Squared Loadings \\
\hline & Total & \% of Variance & Cumulative \% \\
\hline 5 & 1.757 & 3.994 & 45.861 \\
\hline
\end{tabular}

Table 1.10: Variables defining Absorptive Resilience PC5

\begin{tabular}{|c|c|c|}
\hline Variable & $\begin{array}{l}\text { Component } \\
\text { Loading }\end{array}$ & Survey Questions \\
\hline sqrt_q56_all & -0.497 & $\begin{array}{l}\text { Q 5.6 Now I would like to ask you about the type of foods that the } \\
\text { child ate yesterday during day and the night? }\end{array}$ \\
\hline q2443 & 0.375 & $\begin{array}{l}\text { Q 2.4.4 Now I would like to ask you about the types of foods that } \\
\text { you or anyone else in your household ate yesterday during the day } \\
\text { and night?; 3) Any vegetables? }\end{array}$ \\
\hline q257 & 0.372 & $\begin{array}{l}\text { Q 2.5 In the past } 30 \text { days, how frequently did your household use } \\
\text { the following strategies in order to access food?; } 2.5 .7 \text { Use food } \\
\text { from granary or store; }\end{array}$ \\
\hline q261 & -0.355 & $\begin{array}{l}\text { Q 2.6.1 In the past } 12 \text { months, was the household head able to } \\
\text { provide three meals daily for all family members, through own } \\
\text { production purchase or other sources without assistance from } \\
\text { other family members, relatives or NGO? }\end{array}$ \\
\hline q74 & 0.343 & Q 7.4. Is your household directly affected by above conflicts? \\
\hline q2442 & 0.311 & $\begin{array}{l}\text { Q 2.4.4 Now I would like to ask you about the types of foods that } \\
\text { you or anyone else in your household ate yesterday during the day }\end{array}$ \\
\hline
\end{tabular}


Appendix 1: Principal component descriptions and variable loadings

\begin{tabular}{|l|l|l|}
\hline Variable & $\begin{array}{l}\text { Component } \\
\text { Loading }\end{array}$ & Survey Questions \\
\hline & & $\begin{array}{l}\text { and night?; 2) Any potatoes, yams, cassava or any other foods } \\
\text { made from roots or tubers? }\end{array}$ \\
\hline
\end{tabular}

\section{Absorptive Resilience Principal Component 6: Moderate Food Security, and Household Assets}

Households that score highly on this component tend not to experience hunger that requires them to reduce the number of meals or limit portion sizes. They tend (weak to moderate) to have access to land, own basic goods such as shoes, and may have some training in proper diet. Households that score low on this component have a (weak) tendency to rely on less expensive or less preferred foods to deal with food scarcity. Though the tendencies are weak to moderate, this PC demonstrates the situation that household assets tend to provide, or at least indicate, some buffer against food scarcity.

Table 1.11: Variance explained for Absorptive Resilience PC6

\begin{tabular}{|l|l|l|l|}
\hline Component & Initial Eigenvalues & \multicolumn{2}{|l|}{ Extraction Sums of Squared Loadings } \\
\hline & Total & \% of Variance & Cumulative \% \\
\hline 6 & 1.597 & 3.629 & 49.489 \\
\hline
\end{tabular}

Table 1.12: Variables defining Absorptive Resilience PC6

\begin{tabular}{|l|l|l|}
\hline Variable & $\begin{array}{l}\text { Component } \\
\text { Loading }\end{array}$ & Survey Questions \\
\hline q266 & 0.476 & Q 2.6.6 Does the household have access to land? \\
\hline q251 & 0.444 & $\begin{array}{l}\text { Q 2.5 In the past 30 days, how frequently did your household use the } \\
\text { following strategies in order to access food?; 2.5.1 Limit portion size } \\
\text { at meal times? }\end{array}$ \\
\hline q252 & 0.420 & $\begin{array}{l}\text { Q 2.5 In the past 30 days, how frequently did your household use the } \\
\text { following strategies in order to access food?; 2.5.2 Reduce number of } \\
\text { meals eaten per day? }\end{array}$ \\
\hline q255 & -0.391 & $\begin{array}{l}\text { Q 2.5 In the past 30 days, how frequently did your household use the } \\
\text { following strategies in order to access food?; } 2.5 .5 \text { Rely on less } \\
\text { expensive or less preferred foods? }\end{array}$ \\
\hline
\end{tabular}


Appendix 1: Principal component descriptions and variable loadings

\begin{tabular}{|l|l|l|}
\hline Variable & $\begin{array}{l}\text { Component } \\
\text { Loading }\end{array}$ & Survey Questions \\
\hline q241 & 0.382 & Q 2.4.1 Anyone trained in proper diet? \\
\hline q2614 & 0.300 & $\begin{array}{l}\text { Q 2.6.14 Does every member of the household have at least one pair } \\
\text { of shoes? }\end{array}$ \\
\hline
\end{tabular}

\section{Absorptive Resilience Principal Component 7: Families with Absence of Conflict}

Households that score highly on this component tend (moderately) to not experience conflict, and tend (weakly) to have children that ate some form of nutritious food in the previous day. There is also a weak tendency to be able to afford basic goods (clothes). Note that this PC seems to identify a set of households that have different and contrasting relationships among conflict and household assets than does PC 4. This may be due to survey questions associated with this PC addressing "conflicts within your community" rather than simply referring to "conflict" which could be interpreted as associated with armed conflict (which is prevalent in South Sudan due to civil war).

Table 1.13: Variance explained for Absorptive Resilience PC7

\begin{tabular}{|l|l|l|l|}
\hline Component & Initial Eigenvalues & \multicolumn{2}{|l|}{ Extraction Sums of Squared Loadings } \\
\hline & Total & $\%$ of Variance & Cumulative \% \\
\hline 7 & 1.518 & 3.45 & 52.94 \\
\hline
\end{tabular}

Table 1.14: Variables defining Absorptive Resilience PC7

\begin{tabular}{|l|l|l|}
\hline Variable & $\begin{array}{l}\text { Component } \\
\text { Loading }\end{array}$ & Survey Questions \\
\hline q71_q72n & 0.588 & $\begin{array}{l}\text { Q 7.1. Do you have any conflicts within your community; Q } \\
\text { 7.2. If yes, what types of conflicts are within your community? }\end{array}$ \\
\hline q74 & 0.578 & Q 7.4. Is your household directly affected by above conflicts? \\
\hline q2612 & 0.339 & $\begin{array}{l}\text { Q 2.6.12 Does every member of the household have at least two } \\
\text { sets of clothes? }\end{array}$ \\
\hline q58_all & 0.338 & $\begin{array}{l}\text { Q 5.8 What nutritious supplementary infant foods do you know } \\
\text { about? }\end{array}$ \\
\hline
\end{tabular}


Appendix 1: Principal component descriptions and variable loadings

\begin{tabular}{|l|l|l|}
\hline Variable & $\begin{array}{l}\text { Component } \\
\text { Loading }\end{array}$ & Survey Questions \\
\hline sqrt_q56_all & 0.329 & $\begin{array}{l}\text { Q 5.6 Now I would like to ask you about the type of foods that } \\
\text { the child ate yesterday during day and the night }\end{array}$ \\
\hline
\end{tabular}

Absorptive Resilience Principal Component 8: Precarious Food Security, Assets and Land Households that score strongly on this component have a weak tendency to report having eaten vegetables in the previous day, but all other types of foods consumed are not related to this component. Households that score low on this component tend not to have access to land and not to own domestic animals.

Table 1.15: Variance explained for Absorptive Resilience PC8

\begin{tabular}{|l|l|l|l|}
\hline Component & Initial Eigenvalues & Extraction Sums of Squared Loadings \\
\hline & Total & \% of Variance & Cumulative \% \\
\hline 8 & 1.168 & 2.655 & 55.595 \\
\hline
\end{tabular}

Table 1.16: Variables defining Absorptive Resilience PC8

\begin{tabular}{|l|l|l|}
\hline Variable & $\begin{array}{l}\text { Component } \\
\text { Loading }\end{array}$ & Survey Questions \\
\hline q43 & -0.417 & Q 4.3. Does your household own any domestic animals? \\
\hline q266 & -0.395 & Q 2.6.6 Does the household have access to land? \\
\hline q2443 & 0.366 & $\begin{array}{l}\text { Q 2.4.4 Now I would like to ask you about the types of foods that you } \\
\text { or anyone else in your household ate yesterday during the day and } \\
\text { night?; 3) Any vegetables? }\end{array}$ \\
\hline
\end{tabular}

\section{Absorptive Resilience Principal Component 9: Self-sufficiency of Food}

This component is defined by a single variable that describes (strongly) households that have reported a main source of (how they obtained) food in the past month. Both the coding of the input variable and some very weak negative loadings $(<.3)$ imply that this is related to the security that households derive from growing their own food. 
Appendix 1: Principal component descriptions and variable loadings

Table 1.17: Variance explained for Absorptive Resilience PC9

\begin{tabular}{|l|l|l|l|}
\hline Component & Initial Eigenvalues & \multicolumn{2}{|l|}{ Extraction Sums of Squared Loadings } \\
\hline & Total & \% of Variance & Cumulative \% \\
\hline 9 & 1.132 & 2.574 & 58.169 \\
\hline
\end{tabular}

Table 1.18: Variables defining Absorptive Resilience PC9

\begin{tabular}{|l|l|l|}
\hline Variable & Factor Score & Survey Questions \\
\hline q2610 & 0.730 & $\begin{array}{l}\text { Q 2.6.10 Over the past month, what has been the MAIN source } \\
\text { of food consumed by your household? }\end{array}$ \\
\hline
\end{tabular}

\section{Absorptive Resilience Principal Component 10: Good Prenatal Nutrition}

This component describes a moderate tendency in female respondents to have adequate food consumption during pregnancy. Households that score low on this component tend to lack knowledge about nutritious infant foods.

Table 1.19: Variance explained for Absorptive Resilience PC10

\begin{tabular}{|l|l|l|l|}
\hline Component & Initial Eigenvalues & \multicolumn{2}{|l|}{ Extraction Sums of Squared Loadings } \\
\hline & Total & $\%$ of Variance & Cumulative \% \\
\hline 10 & 1.105 & 2.511 & 60.68 \\
\hline
\end{tabular}

Table 1.20: Variables defining Absorptive Resilience PC10

\begin{tabular}{|l|l|l|}
\hline Variable & $\begin{array}{l}\text { Component } \\
\text { Loading }\end{array}$ & Survey Questions \\
\hline q510 & 0.590 & $\begin{array}{l}\text { Q 5.10. During the most recent pregnancy, how much food did you } \\
\text { consume? }\end{array}$ \\
\hline q2610 & 0.425 & $\begin{array}{l}\text { Q 2.6.10 Over the past month, what has been the MAIN source of } \\
\text { food consumed by your household? }\end{array}$ \\
\hline q58_all & -0.329 & $\begin{array}{l}\text { Q 5.8 What nutritious supplementary infant foods do you know } \\
\text { about? }\end{array}$ \\
\hline
\end{tabular}


Appendix 1: Principal component descriptions and variable loadings

\section{Absorptive Resilience Principal Component 11: Prenatal Food Scarcity}

Households that score highly on this component have weak tendencies not to have experienced economic loss, and to have fed their children in the previous day. Households that score low on this component have a moderate tendency to report lack of adequate food during pregnancy.

Table 1.21: Variance explained for Absorptive Resilience PC11

\begin{tabular}{|l|l|l|l|}
\hline Component & Initial Eigenvalues & Extraction Sums of Squared Loadings \\
\hline & Total & \% of Variance & Cumulative \% \\
\hline 11 & 1.053 & 2.393 & 63.073 \\
\hline
\end{tabular}

Table 1.22: Variables defining Absorptive Resilience PC11

\begin{tabular}{|l|l|l|}
\hline Variable & $\begin{array}{l}\text { Component } \\
\text { Loading }\end{array}$ & Survey Questions \\
\hline q510 & -0.519 & $\begin{array}{l}\text { Q 5.10. During the most recent pregnancy, how much food did you } \\
\text { consume? }\end{array}$ \\
\hline q269a & 0.331 & $\begin{array}{l}\text { Q 2.6.9 In the last 12 months (mention the month) did the } \\
\text { household experience any adverse event that led to an economic } \\
\text { loss? }\end{array}$ \\
\hline $\begin{array}{l}\text { sqrt_q56_ } \\
\text { all }\end{array}$ & 0.307 & $\begin{array}{l}\text { Q 5.6 Now I would like to ask you about the type of foods that the } \\
\text { child ate yesterday during day and the night? }\end{array}$ \\
\hline
\end{tabular}


Appendix 1: Principal component descriptions and variable loadings

ADAPTIVE RESILIENCE

\section{Identification of Principal Components}

The Adaptive Resilience dataset that was prepared for Principal Components Analysis consisted of 23 variables and 800 records. Eight components were retained and interpreted as latent variables, explaining $67.2 \%$ of variance in the dataset. These were identified as:

- Component 1: Organized Disaster Management

- Component 2: Disaster Management (not organized)

- Component 3: "Other" Environmental Conservation and Farming

- Component 4: “Other” Environmental Conservation and Charcoal Burning

- Component 5: High Education and Income

- Component 6: Awareness of conservation, disaster and conflict

- Component 7: Stable Income and Education

- Component 8: Secure Income

\section{Adaptive Resilience Principal Component 1: Organized Disaster Management}

Households that score highly on this PC are those that tend (strongly) to have and are aware of village disaster management committees. They tend (moderately to weakly) to employ and be aware of disaster management, conservation and beneficial farming practices, and to be aware of practices that cause environmental destruction. Households that score low on this component tend (strongly) to have faced a disaster in the last 12 months and (moderately) not to have employed an effective disaster-risk reduction or positive coping strategy. The associations evident in the variables that define this PC suggest that capacity at the community level has mitigated against the impact of disasters, and this is why household level responses about awareness of adaptive strategies and disaster management committees seem to be opposed to the actual experience of disaster in the last 12 months.

Table 1.23: Variance explained for Adaptive Resilience PC1

\begin{tabular}{|l|l|l|l|}
\hline Component & Initial Eigenvalues & \multicolumn{2}{|l|}{ Extraction Sums of Squared Loadings } \\
\hline & Total & $\%$ of Variance & Cumulative \% \\
\hline 1 & 4.015 & 17.458 & 17.458 \\
\hline
\end{tabular}


Appendix 1: Principal component descriptions and variable loadings

Table 1.24: Variables defining Adaptive Resilience PC1

\begin{tabular}{|c|c|c|}
\hline Variable & $\begin{array}{l}\text { Component } \\
\text { Loading }\end{array}$ & Survey Questions \\
\hline q719 & 0.806 & $\begin{array}{l}\text { Q7.19. If yes, does this community have a disaster management } \\
\text { committee? }\end{array}$ \\
\hline q718 & 0.799 & $\begin{array}{l}\text { Q7.18. Have you ever heard about a disaster management } \\
\text { committee? }\end{array}$ \\
\hline q715 & -0.788 & $\begin{array}{l}\text { Q7.15. Did you household face any disaster in the past } 12 \\
\text { months? }\end{array}$ \\
\hline $\mathrm{q} 714$ & 0.587 & $\begin{array}{l}\text { Q7.14. Do you know of any potential disasters that are likely to } \\
\text { occur in your community? }\end{array}$ \\
\hline q717 & -0.493 & $\begin{array}{l}\text { Q7.17 Was your household able to employ an effective disaster- } \\
\text { risk reduction or positive coping strategy to avoid disaster at the } \\
\text { household level? }\end{array}$ \\
\hline Log10_q35_all & 0.491 & $\begin{array}{l}\text { Q 3.5 Which of the following farming practices did this } \\
\text { household use during the last farming season? }\end{array}$ \\
\hline Log10_q318_all & 0.473 & $\begin{array}{l}\text { Q3. 18. Which of the following farming strategies that reduce risk } \\
\text { to disaster and climate change does this household use? }\end{array}$ \\
\hline q31 & 0.417 & Q 3.1 Did you plant any crops during the last farming seasons? \\
\hline $\mathrm{q} 723 \mathrm{c}$ & 0.371 & $\begin{array}{l}\text { Q7.23. What is your household doing to promote environment } \\
\text { conservation in this area?; adopting good farming practices }\end{array}$ \\
\hline q721 & 0.371 & Q7.2. If yes, what types of conflicts are within your community? \\
\hline q722c & 0.356 & $\begin{array}{l}\text { Q7.22. What are the practices in this area that are contributing to } \\
\text { environment destructions?; poor farming methods }\end{array}$ \\
\hline q722a & 0.334 & $\begin{array}{l}\text { Q7.22. What are the practices in this area that are contributing to } \\
\text { environment destructions?; Cutting of trees }\end{array}$ \\
\hline q723a & 0.317 & $\begin{array}{l}\text { Q7.23. What is your household doing to promote environment } \\
\text { conservation in this area?; Planting tree }\end{array}$ \\
\hline $\mathrm{q} 723 \mathrm{~b}$ & 0.307 & $\begin{array}{l}\text { Q7.23. What is your household doing to promote environment } \\
\text { conservation in this area?; Not burning charcoal }\end{array}$ \\
\hline
\end{tabular}


Appendix 1: Principal component descriptions and variable loadings

Adaptive Resilience Principal Component 2: Disaster Management (not organized)

Households that score highly on this PC tend (moderately) to have employed an effective disaster-risk reduction or positive coping strategy. They tend (moderately to weakly) to employ and be aware disaster management, conservation and beneficial farming practices, and to be aware of practices that cause environmental destruction. Households that score low on this component tend (moderately) not to have community disaster management committees, nor to have heard of them. This PC contrasts with PC1 and could identify a target for programming. With the caveat that the sampling design of the 2015 survey was not designed to be representative at the village (boma) level, future work should pay attention to this question, to understand and contrast the experience of households in different communities with and without disaster management adaptive capacities.

Table 1.25: Variance explained for Adaptive Resilience PC2

\begin{tabular}{|l|l|l|l|}
\hline Component & Initial Eigenvalues & Extraction Sums of Squared Loadings \\
\hline & Total & \% of Variance & Cumulative \% \\
\hline 2 & 2.709 & 11.777 & 29.234 \\
\hline
\end{tabular}

Table 1.26: Variables defining Adaptive Resilience PC2

\begin{tabular}{|l|l|l|}
\hline Variable & $\begin{array}{l}\text { Component } \\
\text { Loading }\end{array}$ & Survey Questions \\
\hline q717 & 0.533 & $\begin{array}{l}\text { Q7.17 Was your household able to employ an effective disaster- } \\
\text { risk reduction or positive coping strategy to avoid disaster at the } \\
\text { household level? }\end{array}$ \\
\hline q723b & 0.515 & $\begin{array}{l}\text { Q7.23. What is your household doing to promote environment } \\
\text { conservation in this area?; Not burning charcoal }\end{array}$ \\
\hline q719 & -0.510 & $\begin{array}{l}\text { Q7.19. If yes, does this community have a disaster management } \\
\text { committee? }\end{array}$ \\
\hline q722b & 0.508 & $\begin{array}{l}\text { Q7.22. What are the practices in this area that are contributing to } \\
\text { environment destructions?; Charcoal Bunning }\end{array}$ \\
\hline q722a & 0.506 & $\begin{array}{l}\text { Q7.22. What are the practices in this area that are contributing to } \\
\text { environment destructions?; Cutting of trees }\end{array}$ \\
\hline q723a & 0.485 & $\begin{array}{l}\text { Q7.23. What is your household doing to promote environment } \\
\text { conservation in this area?; Planting tree }\end{array}$ \\
\hline
\end{tabular}


Appendix 1: Principal component descriptions and variable loadings

\begin{tabular}{|l|l|l|}
\hline Variable & $\begin{array}{l}\text { Component } \\
\text { Loading }\end{array}$ & Survey Questions \\
\hline q718 & -0.471 & $\begin{array}{l}\text { Q7.18. Have you ever heard about a disaster management } \\
\text { committee? }\end{array}$ \\
\hline q723c & 0.457 & $\begin{array}{l}\text { Q7.23. What is your household doing to promote environment } \\
\text { conservation in this area?; adopting good farming practices }\end{array}$ \\
\hline q715 & 0.397 & $\begin{array}{l}\text { Q7.15. Did you household face any disaster in the past 12 } \\
\text { months? }\end{array}$ \\
\hline q31 & 0.335 & Q 3.1 Did you plant any crops during the last farming seasons? \\
\hline q722c & 0.326 & $\begin{array}{l}\text { Q7.22. What are the practices in this area that are contributing to } \\
\text { environment destructions?; poor farming methods }\end{array}$ \\
\hline Log10_q35_all & 0.321 & $\begin{array}{l}\text { Q 3.5 Which of the following farming practices did this } \\
\text { household use during the last farming season? }\end{array}$ \\
\hline Log10_q318_all & 0.320 & $\begin{array}{l}\text { Q3. 18. Which of the following farming strategies that reduce risk } \\
\text { to disaster and climate change does this household use? }\end{array}$ \\
\hline
\end{tabular}

\section{Adaptive Resilience Principal Component 3: "Other" Environmental Conservation and Farming}

Households that score highly on this component tended (low to moderately) to report action to conserve the environment in the "other" category, and to be aware of "other" category practices that are harmful to the environment. Households that score low on this component tended (moderately) not to have planted crops in the previous season, nor to have employed farming conservation practices or disaster and climate change risk reduction strategies. Though most respondents in the villages surveyed will derive their livelihoods from the land, it may be that this PC identifies respondents who are not farmers.

Table 1.27: Variance explained for Adaptive Resilience PC3

\begin{tabular}{|l|l|l|l|}
\hline Component & Initial Eigenvalues & Extraction Sums of Squared Loadings \\
\hline & Total & $\%$ of Variance & Cumulative \% \\
\hline 3 & 2.218 & 9.643 & 38.878 \\
\hline
\end{tabular}


Appendix 1: Principal component descriptions and variable loadings

Table 1.28: Variables defining Adaptive Resilience PC3

\begin{tabular}{|l|l|l|}
\hline Variable & $\begin{array}{l}\text { Component } \\
\text { Loading }\end{array}$ & Survey Question \\
\hline Log10_q35_all & -0.686 & $\begin{array}{l}\text { Q 3.5 Which of the following farming practices did this } \\
\text { household use during the last farming season? }\end{array}$ \\
\hline q31 & -0.679 & $\begin{array}{l}\text { Q 3.1 Did you plant any crops during the last farming } \\
\text { seasons?; Q 3.1 Did you plant any crops during the last } \\
\text { farming seasons? }\end{array}$ \\
\hline $\begin{array}{l}\text { Log10_q318_al } \\
1\end{array}$ & -0.638 & $\begin{array}{l}\text { Q3.18. Which of the following farming strategies that } \\
\text { reduce risk to disaster and climate change does this } \\
\text { household use? }\end{array}$ \\
\hline q722d & 0.454 & $\begin{array}{l}\text { Q7.22. What are the practices in this area that are } \\
\text { contributing to environment destructions?; Others (specify) }\end{array}$ \\
\hline q723d & 0.416 & $\begin{array}{l}\text { Q7.23. What is your household doing to promote } \\
\text { environment conservation in this area?; others (specify) }\end{array}$ \\
\hline
\end{tabular}

Adaptive Resilience Principal Component 4: “Other” Environmental Conservation and Charcoal Burning

Households that score highly on this component tended (strongly) to report action to conserve the environment in the "other" category, and to be aware of "other" category practices that are harmful to the environment. Households that score low on this component tended (weakly) not to have reported charcoal burning as environmentally damaging.

Table 1.29: Variance explained for Adaptive Resilience PC4

\begin{tabular}{|l|l|l|l|}
\hline Component & Initial Eigenvalues & \multicolumn{2}{|l|}{ Extraction Sums of Squared Loadings } \\
\hline & Total & $\%$ of Variance & Cumulative \% \\
\hline 4 & 1.658 & 7.21 & 46.088 \\
\hline
\end{tabular}


Appendix 1: Principal component descriptions and variable loadings

Table 1.30: Variables defining Adaptive Resilience PC4

\begin{tabular}{|l|l|l|}
\hline Variable & $\begin{array}{l}\text { Component } \\
\text { Loading }\end{array}$ & Survey Questions \\
\hline q723d & 0.794 & $\begin{array}{l}\text { Q 7.23. What is your household doing to promote } \\
\text { environment conservation in this area?; others (specify) }\end{array}$ \\
\hline q722d & 0.754 & $\begin{array}{l}\text { Q 7.22. What are the practices in this area that are } \\
\text { contributing to environment destructions?; Others (specify) }\end{array}$ \\
\hline q722b & -0.318 & $\begin{array}{l}\text { Q 7.22. What are the practices in this area that are } \\
\text { contributing to environment destructions?; Charcoal } \\
\text { Bunning; }\end{array}$ \\
\hline
\end{tabular}

\section{Adaptive Resilience Principal Component 5: High Education and Income}

Households scoring strongly on this component have moderate tendencies for higher levels of education, alternative sources of income and a (weak) tendency for at least one adult in the household to be earning a regular income. Households that score low on this component tended (weakly) not to have reported adopting good farming practices. Though education is indicated as high in households scoring strongly on this PC, it may point to need for programming such as education and training of farmers on "good farming practices" for conservation.

Table 1.31: Variance explained for Adaptive Resilience PC5

\begin{tabular}{|l|l|l|l|}
\hline Component & Initial Eigenvalues & Extraction Sums of Squared Loadings \\
\hline & Total & $\%$ of Variance & Cumulative \% \\
\hline 5 & 1.526 & 6.635 & 52.723 \\
\hline
\end{tabular}

Table 1.32: Variables defining Adaptive Resilience PC5

\begin{tabular}{|l|l|l|}
\hline Variable & $\begin{array}{l}\text { Component } \\
\text { Loading }\end{array}$ & Survey Questions \\
\hline q114 & 0.654 & $\begin{array}{l}\text { Q 1.14 What is the highest level of education that head of the } \\
\text { household have completed? }\end{array}$ \\
\hline q113 & 0.600 & $\begin{array}{l}\text { Q 1.13 What is the highest level of education that you have } \\
\text { completed? }\end{array}$ \\
\hline
\end{tabular}


Appendix 1: Principal component descriptions and variable loadings

\begin{tabular}{|l|l|l|}
\hline Variable & $\begin{array}{l}\text { Component } \\
\text { Loading }\end{array}$ & Survey Questions \\
\hline q265 & 0.507 & $\begin{array}{l}\text { Q 2.6.5 Does the household have an alternative source of income to } \\
\text { rely on, should the main source of income be lost? }\end{array}$ \\
\hline q41 & 0.372 & $\begin{array}{l}\text { Q41 Is there one or more adults, over 18 years, in the household that is } \\
\text { earning a regular income to meet the needs of the household? }\end{array}$ \\
\hline q723c & -0.363 & $\begin{array}{l}\text { Q 7.23. What is your household doing to promote environment } \\
\text { conservation in this area?; adopting good farming practices }\end{array}$ \\
\hline
\end{tabular}

\section{Adaptive Resilience Principal Component 6: Awareness of conservation, disaster and conflict}

Households that score highly on this component have (weak) tendencies to be aware of potential disasters and conflicts, and to report undertaking environmentally beneficial household practices (not burning charcoal, planting trees). Households that score weakly on this component have a moderate tendency not to report poor farming practices as contributing to environmental destruction. As with PC5, this PC may point to a need for programming such as education and training of farmers on "good farming practices" for conservation.

Table 1.33: Variance explained for Adaptive Resilience PC6

\begin{tabular}{|l|l|l|l|}
\hline Component & Initial Eigenvalues & \multicolumn{2}{|l|}{ Extraction Sums of Squared Loadings } \\
\hline & Total & \% of Variance & Cumulative \% \\
\hline 6 & 1.17 & 5.088 & 57.812 \\
\hline
\end{tabular}

Table 1.34: Variables defining Adaptive Resilience PC6

\begin{tabular}{|l|l|l|}
\hline Variable & $\begin{array}{l}\text { Component } \\
\text { Loading }\end{array}$ & Survey Questions \\
\hline q722c & -0.560 & $\begin{array}{l}\text { Q 7.22. What are the practices in this area that are contributing to } \\
\text { environment destructions?; poor farming methods }\end{array}$ \\
\hline q721 & 0.379 & Q 7.2. If yes, what types of conflicts are within your community? \\
\hline q714 & 0.362 & $\begin{array}{l}\text { Q 7.14. Do you know of any potential disasters that are likely to occur } \\
\text { in your community? }\end{array}$ \\
\hline
\end{tabular}


Appendix 1: Principal component descriptions and variable loadings

\begin{tabular}{|l|l|l|}
\hline Variable & $\begin{array}{l}\text { Component } \\
\text { Loading }\end{array}$ & Survey Questions \\
\hline q723b & 0.349 & $\begin{array}{l}\text { Q 7.23. What is your household doing to promote environment } \\
\text { conservation in this area?; Not burning charcoal }\end{array}$ \\
\hline q723a & 0.326 & $\begin{array}{l}\text { Q 7.23. What is your household doing to promote environment } \\
\text { conservation in this area?; Planting tree }\end{array}$ \\
\hline
\end{tabular}

\section{Adaptive Resilience Principal Component 7: Stable Income and Education}

Households that score strongly on this component report stable sources of income and higher levels of education (weak to moderate). Households that score low on this component have (weak) tendencies for a lack of alternate sources of income and adults earning regular income. Programming around income generating activities, such as skills development in carpentry, tailoring, and business practices (e.g., to support sale of produce at market) may be identified for households that score low on this PC.

Table 1.35: Variance explained for Adaptive Resilience PC7

\begin{tabular}{|l|l|l|l|}
\hline Component & Initial Eigenvalues & \multicolumn{2}{|l|}{ Extraction Sums of Squared Loadings } \\
\hline & Total & $\%$ of Variance & Cumulative \% \\
\hline 7 & 1.105 & 4.804 & 62.616 \\
\hline
\end{tabular}

Table 1.36: Variables defining Adaptive Resilience PC7

\begin{tabular}{|l|l|l|}
\hline Variable & $\begin{array}{l}\text { Component } \\
\text { Loading }\end{array}$ & Survey Questions \\
\hline q264 & 0.480 & Q 2.6.4 What is the main source of household income? \\
\hline q113 & 0.463 & Q 1.13 What is the highest level of education that you have completed? \\
\hline q114 & 0.330 & $\begin{array}{l}\text { Q } 1.14 \text { What is the highest level of education that head of the } \\
\text { household have completed? }\end{array}$ \\
\hline q41 & -0.327 & $\begin{array}{l}\text { Q41 Is there one or more adults, over 18 years, in the household that is } \\
\text { earning a regular income to meet the needs of the household?; Yes }=1, \\
\text { No }=0, \text { DK }=2\end{array}$ \\
\hline
\end{tabular}


Appendix 1: Principal component descriptions and variable loadings

\begin{tabular}{|l|l|l|}
\hline Variable & $\begin{array}{l}\text { Component } \\
\text { Loading }\end{array}$ & Survey Questions \\
\hline q265 & -0.308 & $\begin{array}{l}\text { Q } 2.6 .5 \text { Does the household have an alternative source of income to } \\
\text { rely on, should the main source of income be lost? }\end{array}$ \\
\hline
\end{tabular}

\section{Adaptive Resilience Principal Component 8: Secure Income}

This component describes households that report (strongly) a stable source of income (e.g., remittances and casual labour are not secure, whereas hiring out labour on other farms, and informal and formal business are relatively more secure). They also have a moderate tendency for adults to earn regular income, and a weak tendency for access to alternative sources of income. As with PC7, programming around income generating activities, such as skills development in carpentry, tailoring, and business practices (e.g., to support sale of produce at market) may be identified for households that score low on this PC. The FEED project has already been undertaking such work in South Sudan, and these results both validate the appropriateness of such work and may help to better target project beneficiaries.

Table 1.37: Variance explained for Adaptive Resilience PC8

\begin{tabular}{|l|l|l|l|}
\hline Component & Initial Eigenvalues & \multicolumn{2}{|l|}{ Extraction Sums of Squared Loadings } \\
\hline & Total & $\%$ of Variance & Cumulative \% \\
\hline 8 & 1.042 & 4.53 & 67.146 \\
\hline
\end{tabular}

Table 1.38: Variables defining Adaptive Resilience PC8

\begin{tabular}{|l|l|l|}
\hline Variable & Factor Score & Survey Questions \\
\hline q264 & 0.722 & Q 2.6.4 What is the main source of household income? \\
\hline q41 & 0.426 & $\begin{array}{l}\text { Q4.1 Is there one or more adults, over 18 years, in the } \\
\text { household that is earning a regular income to meet the needs } \\
\text { of the household? }\end{array}$ \\
\hline q265 & 0.323 & $\begin{array}{l}\text { Q 2.6.5 Does the household have an alternative source of } \\
\text { income to rely on, should the main source of income be lost? }\end{array}$ \\
\hline
\end{tabular}


Appendix 1: Principal component descriptions and variable loadings

\section{TRANSFORMATIVE RESILIENCE}

\section{Identification of Principal Components}

The transformative resilience dataset that was prepared for Principal Components Analysis consisted of 30 variables and 804 records. Nine principal components were retained and described as latent variables, explaining $68.4 \%$ of variance in the dataset:

- Component 1: Gender and Women's Empowerment

- Component 2: Community-level Social Capital

- Component 3: Agricultural Success and Access to Financial Institutions

- Component 4: Gender Awareness

- Component 5: Absence of Gender-based Violence

- Component 6: Access to Financial Services

- Component 7: Access to Land for Cultivation

- Component 8: Gender and Equal Opportunity

- Component 9: Women's Empowerment and Access to Farming Inputs

Transformative Resilience Principal Component 1: Gender and Women's Empowerment Households that score highly on this PC responded positively to a large number of questions relating to gender and women's empowerment. These are more resilient with respect to transformative resilience than households that score low on this PC. Thirteen such questions define this component, and all are strongly or moderately correlated to the component. These point to potential programming pertaining to gender equality to support transformative resilience.

Table 1.39: Variance explained for Transformative Resilience PC1

\begin{tabular}{|l|l|l|l|}
\hline Component & Initial Eigenvalues & \multicolumn{2}{|c|}{ Extraction Sums of Squared Loadings } \\
\hline & Total & \% of Variance & Cumulative \% \\
\hline 1 & 4.015 & 17.458 & 17.458 \\
\hline
\end{tabular}

Table 1.40: Variables defining Transformative Resilience PC1

\begin{tabular}{|l|l|l|}
\hline Variable & $\begin{array}{l}\text { Component } \\
\text { Loading }\end{array}$ & Survey Questions \\
\hline $\mathrm{q} 68 \mathrm{n}$ & 0.761 & $\begin{array}{l}\text { Q 6.8 Women's views are taken into consideration by the } \\
\text { community? }\end{array}$ \\
\hline $\mathrm{q} 69 \mathrm{n}$ & 0.733 & Q 6.9 Women participate freely in community events? \\
\hline
\end{tabular}


Appendix 1: Principal component descriptions and variable loadings

\begin{tabular}{|l|l|l|}
\hline Variable & $\begin{array}{l}\text { Component } \\
\text { Loading }\end{array}$ & Survey Questions \\
\hline q610n & 0.709 & $\begin{array}{l}\text { Q 6.10 Women and men are equally targeted for } \\
\text { development activities? }\end{array}$ \\
\hline q66n & 0.704 & $\begin{array}{l}\text { Q 6.6 Men and women are given equal opportunity to } \\
\text { develop their skills? }\end{array}$ \\
\hline q614n & 0.701 & $\begin{array}{l}\text { Q 6.14 Women have a role in decision making about } \\
\text { farming activities for their households, public speaking, } \\
\text { and policy making? }\end{array}$ \\
\hline q67n & 0.671 & $\begin{array}{l}\text { Q 6.7 Local leaders aware of the different needs of women } \\
\text { and men }\end{array}$ \\
\hline q612n & 0.664 & Q 6.12 Women have control over land? \\
\hline q611n & 0.635 & Q 6.11 Women have access to land \\
\hline q613n & 0.612 & $\begin{array}{l}\text { Q 6.13 Women have control over agricultural produce and } \\
\text { proceeds their households, public speaking, and policy } \\
\text { making? }\end{array}$ \\
\hline q65n & 0.583 & $\begin{array}{l}\text { Q 6.5 Respondent appreciates the different gender roles in } \\
\text { the community? }\end{array}$ \\
\hline q61n & 0.534 & Q 6.1 Boys and girls are equally valued by the community? \\
\hline q63n & 0.521 & Q 6.3 Boys and girls are given equal protection in families? \\
\hline q62n & 0.456 & $\begin{array}{l}\text { Q 6.2 Boys and girls are given equal opportunity to attend } \\
\text { school? }\end{array}$ \\
\hline
\end{tabular}

\section{Transformative Resilience Principal Component 2: Community-level Social Capital}

Households that score highly on this PC are those in which males and females participate in "common interest groups" (such as farmers groups, cooperatives, market, horticultural or traders' groups, or local NGOs), and which have access to financial institutions, land and agricultural inputs. Participation in common interest groups defines this component (strongly), more than do the access variables (weakly). 
Appendix 1: Principal component descriptions and variable loadings

Table 1.41: Variance explained for Transformative Resilience PC2

\begin{tabular}{|l|l|l|l|}
\hline Component & Initial Eigenvalues & \multicolumn{2}{|l|}{ Extraction Sums of Squared Loadings } \\
\hline & Total & \% of Variance & Cumulative \% \\
\hline 2 & 2.709 & 11.777 & 29.234 \\
\hline
\end{tabular}

Table 1.42: Variables defining Transformative Resilience PC2

\begin{tabular}{|c|c|c|}
\hline Variable & $\begin{array}{l}\text { Component } \\
\text { Loading }\end{array}$ & Survey Questions \\
\hline Q3.7m_binary & 0.870 & $\begin{array}{l}\text { Q } 3.7 \mathrm{~m} \text { List types of common interest groups to which } \\
\text { the respondent belongs (male) }\end{array}$ \\
\hline q36_binary & 0.868 & $\begin{array}{l}\text { Q } 3.6 \text { Are you aware of any common interest group in } \\
\text { this area? }\end{array}$ \\
\hline Q3.7f_binary & 0.811 & $\begin{array}{l}\text { Q 3.7f List types of common interest groups to which } \\
\text { the respondent belongs. (female) }\end{array}$ \\
\hline q38m+f_all & 0.800 & $\begin{array}{l}\text { Have you or anyone in your household completed a } \\
\text { training cycle? (If you belong to one of the above } \\
\text { groups) }\end{array}$ \\
\hline q267b & 0.366 & $\begin{array}{l}\text { Q 2.6.7 During the last agricultural season, how many } \\
\text { acres of land did the household own and cultivate?; B) } \\
\text { Land Cultivated }\end{array}$ \\
\hline $\begin{array}{l}\text { q629- } \\
\text { q630_all_binary }\end{array}$ & 0.338 & $\begin{array}{l}\text { Q6.29-6.30 Which group or community structures do } \\
\text { you hold leadership position in? }\end{array}$ \\
\hline q267a & 0.337 & $\begin{array}{l}\text { Q 2.6.7 During the last agricultural season, how many } \\
\text { acres of land did the household own and cultivate?; A) } \\
\text { Land Owned; }\end{array}$ \\
\hline$q 47 b$ & 0.327 & $\begin{array}{l}\text { Q 4.7 Did any member of this household access a } \\
\text { service from a self-selected village savings and loans } \\
\text { groups or bank loans within the last } 12 \text { months?; } \\
\text { Female }\end{array}$ \\
\hline
\end{tabular}


Appendix 1: Principal component descriptions and variable loadings

\begin{tabular}{|l|l|l|}
\hline Variable & $\begin{array}{l}\text { Component } \\
\text { Loading }\end{array}$ & Survey Questions \\
\hline q33_all_binary & 0.308 & $\begin{array}{l}\text { Q 3.3 During the last planting season (six months), } \\
\text { which of the following farming inputs were you able to } \\
\text { access/receive? }\end{array}$ \\
\hline
\end{tabular}

\section{Transformative Resilience Principal Component 3: Agricultural Success and Access to Financial Institutions}

This component is (moderately) defined by households that sold agricultural produce in the last year, and tended (strongly) to get a high price for those products. Male and female access to financial services also weakly contribute to the definition of this component. The relationship of access to self-selected village savings and loans groups (self-help groups), or bank loans, to this component suggests that this may be an area for further investigation and potential programming.

Table 1.43: Variance explained for Transformative Resilience PC3

\begin{tabular}{|l|l|l|l|}
\hline Component & Initial Eigenvalues & \multicolumn{2}{|c|}{ Extraction Sums of Squared Loadings } \\
\hline & Total & $\%$ of Variance & Cumulative \% \\
\hline 3 & 2.218 & 9.643 & 38.878 \\
\hline
\end{tabular}

Table 1.44: Variables defining Transformative Resilience PC3

\begin{tabular}{|l|l|l|}
\hline Variable & $\begin{array}{l}\text { Component } \\
\text { Loading }\end{array}$ & Survey Question \\
\hline q321b & 0.877 & $\begin{array}{l}\text { Q 3.22 Did you or any member of this household obtain high } \\
\text { prices/returns on the sale of agricultural produces in the last } \\
6 \text { months?; Female }\end{array}$ \\
\hline $\mathrm{q} 321 \mathrm{a}$ & 0.868 & $\begin{array}{l}\text { Q 3.22 Did you or any member of this household obtain high } \\
\text { prices/returns on the sale of agricultural produces in the last } \\
6 \text { months?; Male }\end{array}$ \\
\hline $\mathrm{q} 319$ & 0.582 & Q 3.20 Did you sell any of your crop harvests last season? \\
\hline $\mathrm{q} 47 \mathrm{a}$ & 0.382 & $\begin{array}{l}\text { Q 4.7 Did any member of this household access a service } \\
\text { from a self-selected village savings and loans groups or bank } \\
\text { loans within the last 12 months?; Male }\end{array}$ \\
\hline
\end{tabular}


Appendix 1: Principal component descriptions and variable loadings

\begin{tabular}{|l|l|l|}
\hline q47b & 0.381 & $\begin{array}{l}\text { Q 4.7 Did any member of this household access a service } \\
\text { from a self-selected village savings and loans groups or bank } \\
\text { loans within the last } 12 \text { months?; Female }\end{array}$ \\
\hline
\end{tabular}

\section{Transformative Resilience Principal Component 4: Gender Awareness}

This component describes households that did not experience nor know of gender violence (moderate) and that value boys and girls equally (weakly). Access to land also (weakly) helped to describe this component. Households that scored low on this component are those in which women tend (weakly) not to have control over agricultural products and proceeds, and in which the respondent would tend (weakly) not to report gender violence.

Table 1.45: Variance explained for Transformative Resilience PC4

\begin{tabular}{|l|l|l|l|}
\hline Component & Initial Eigenvalues & Extraction Sums of Squared Loadings \\
\hline & Total & \% of Variance & Cumulative \% \\
\hline 4 & 1.658 & 7.21 & 46.088 \\
\hline
\end{tabular}

Table 1.46: Variables defining Transformative Resilience PC4

\begin{tabular}{|l|l|l|}
\hline Variable & $\begin{array}{l}\text { Component } \\
\text { Loading }\end{array}$ & Survey Questions \\
\hline q623 & 0.619 & $\begin{array}{l}\text { Q 6.23 Over the last 6 months, have you heard of any community } \\
\text { member who experienced Gender based Violence }\end{array}$ \\
\hline q621 & 0.560 & $\begin{array}{l}\text { Q 6.21 Over the last 6 months, did you or any female household } \\
\text { member experience any form of Gender based violence }\end{array}$ \\
\hline q267a & 0.392 & $\begin{array}{l}\text { Q 2.6.7 During the last agricultural season, how many acres of } \\
\text { land did the household own and cultivate?; A) Land Owned }\end{array}$ \\
\hline q267b & 0.389 & $\begin{array}{l}\text { Q 2.6.7 During the last agricultural season, how many acres of } \\
\text { land did the household own and cultivate?; B) Land Cultivated }\end{array}$ \\
\hline q627 & -0.351 & $\begin{array}{l}\text { Q 6.27 If you suspected that a girl child or woman in the } \\
\text { community was being abused (physically or sexually), would you } \\
\text { willing to report such an incident? }\end{array}$ \\
\hline q61n & 0.332 & Q 6.1 Boys and girls are equally valued by the community? \\
\hline
\end{tabular}


Appendix 1: Principal component descriptions and variable loadings

\begin{tabular}{|l|l|l|}
\hline Variable & $\begin{array}{l}\text { Component } \\
\text { Loading }\end{array}$ & Survey Questions \\
\hline q613n & -0.304 & $\begin{array}{l}\text { Q 6.13 Women have control over agricultural produce and } \\
\text { proceeds their households, public speaking, and policy making? }\end{array}$ \\
\hline
\end{tabular}

Transformative Resilience Principal Component 5: Absence of Gender-based Violence Households scoring strongly on this component tend (moderately) not to have experienced, nor know of, gender-based violence in the community. Households that score low on this component tend (weakly) not to have access to land for cultivation.

Table 1.47: Variance explained for Transformative Resilience PC5

\begin{tabular}{|l|l|l|l|}
\hline Component & Initial Eigenvalues & \multicolumn{2}{|c|}{ Extraction Sums of Squared Loadings } \\
\hline & Total & \% of Variance & Cumulative \% \\
\hline 5 & 1.526 & 6.635 & 52.723 \\
\hline
\end{tabular}

Table 1.48: Variables defining Transformative Resilience PC5

\begin{tabular}{|l|l|l|}
\hline Variable & $\begin{array}{l}\text { Component } \\
\text { Loading }\end{array}$ & Survey Questions \\
\hline q621 & 0.530 & $\begin{array}{l}\text { Q 6.21 Over the last 6 months, did you or any female household } \\
\text { member experience any form of Gender based violence }\end{array}$ \\
\hline q623 & 0.506 & $\begin{array}{l}\text { Q 6.23 Over the last 6 months, have you heard of any community } \\
\text { member who experienced Gender based Violence }\end{array}$ \\
\hline q267b & -0.347 & $\begin{array}{l}\text { Q 2.6.7 During the last agricultural season, how many acres of } \\
\text { land did the household own and cultivate?; B) Land Cultivated }\end{array}$ \\
\hline q267a & -0.316 & $\begin{array}{l}\text { Q 2.6.7 During the last agricultural season, how many acres of } \\
\text { land did the household own and cultivate?; A) Land Owned }\end{array}$ \\
\hline
\end{tabular}

\section{Transformative Resilience Principal Component 6: Access to Financial Services}

The most strongly contributing variables to this component are (moderately) female and male access to financial services. Households scoring strongly on this component also tend (weakly) to have access to land for cultivation. Households that score low on this component tended (weakly) to report that boys and girls were not valued equally in the community. 
Appendix 1: Principal component descriptions and variable loadings

Table 1.49: Variance explained for Transformative Resilience PC6

\begin{tabular}{|l|l|l|l|}
\hline Component & Initial Eigenvalues & \multicolumn{2}{|l|}{ Extraction Sums of Squared Loadings } \\
\hline & Total & $\%$ of Variance & Cumulative \% \\
\hline 6 & 1.17 & 5.088 & 57.812 \\
\hline
\end{tabular}

Table 1.50: Variables defining Transformative Resilience PC6

\begin{tabular}{|l|l|l|}
\hline Variable & $\begin{array}{l}\text { Component } \\
\text { Loading }\end{array}$ & Survey Questions \\
\hline q47b & 0.526 & $\begin{array}{l}\text { Q 4.7 Did any member of this household access a service } \\
\text { from a self-selected village savings and loans groups or } \\
\text { bank loans within the last 12 months?; Female }\end{array}$ \\
\hline q47a & 0.491 & $\begin{array}{l}\text { Q 4.7 Did any member of this household access a service } \\
\text { from a self-selected village savings and loans groups or } \\
\text { bank loans within the last 12 months?; Male }\end{array}$ \\
\hline q267a & 0.395 & $\begin{array}{l}\text { Q 2.6.7 During the last agricultural season, how many } \\
\text { acres of land did the household own and cultivate?; A) } \\
\text { Land Owned }\end{array}$ \\
\hline q267b & 0.376 & $\begin{array}{l}\text { Q 2.6.7 During the last agricultural season, how many } \\
\text { acres of land did the household own and cultivate?; B) } \\
\text { Land Cultivated }\end{array}$ \\
\hline q61n & -0.331 & $\begin{array}{l}\text { Q 6.1 Boys and girls are equally valued by the } \\
\text { community? }\end{array}$ \\
\hline
\end{tabular}

\section{Transformative Resilience Principal Component 7: Access to Land for Cultivation}

Households that score highly on this component tend (weak to moderately) to have access to land for cultivation (both land owned and other land cultivated). Households that score low on this component have weak tendencies to lack access to financial services and agricultural inputs. 
Appendix 1: Principal component descriptions and variable loadings

Table 1.51: Variance explained for Transformative Resilience PC7

\begin{tabular}{|l|l|l|l|}
\hline Component & Initial Eigenvalues & \multicolumn{2}{|l|}{ Extraction Sums of Squared Loadings } \\
\hline & Total & $\%$ of Variance & Cumulative \% \\
\hline 7 & 1.105 & 4.804 & 62.616 \\
\hline
\end{tabular}

Table 1.52: Variables defining Transformative Resilience PC7

\begin{tabular}{|l|l|l|}
\hline Variable & $\begin{array}{l}\text { Component } \\
\text { Loading }\end{array}$ & Survey Questions \\
\hline q267a & 0.461 & $\begin{array}{l}\text { Q 2.6.7 During the last agricultural season, how many acres } \\
\text { of land did the household own and cultivate?; A) Land } \\
\text { Owned }\end{array}$ \\
\hline q267b & 0.451 & $\begin{array}{l}\text { Q 2.6.7 During the last agricultural season, how many acres } \\
\text { of land did the household own and cultivate?; B) Land } \\
\text { Cultivated }\end{array}$ \\
\hline q47a & -0.431 & $\begin{array}{l}\text { Q 4.7 Did any member of this household access a service } \\
\text { from a self-selected village savings and loans groups or } \\
\text { bank loans within the last 12 months?; Male }\end{array}$ \\
\hline q47b & -0.369 & $\begin{array}{l}\text { Q 4.7 Did any member of this household access a service } \\
\text { from a self-selected village savings and loans groups or } \\
\text { bank loans within the last 12 months?; Female }\end{array}$ \\
\hline q33_all_binary & -0.302 & $\begin{array}{l}\text { Q 3.3 During the last planting season (six months), which } \\
\text { of the following farming inputs were you able to } \\
\text { access/receive? }\end{array}$ \\
\hline
\end{tabular}

Transformative Resilience Principal Component 8: Gender and Equal Opportunity This component describes households that report (weak to moderate) tendencies for both boys and girls have opportunities to attend school, and for women to participate in household decision making. Households that score low on this component report (weak) tendencies for local leaders not to be aware of different needs of women and men. 
Appendix 1: Principal component descriptions and variable loadings

Table 1.53: Variance explained for Transformative Resilience PC8

\begin{tabular}{|l|l|l|l|}
\hline Component & Initial Eigenvalues & Extraction Sums of Squared Loadings \\
\hline & Total & $\%$ of Variance & Cumulative \% \\
\hline 8 & 1.042 & 4.53 & 67.146 \\
\hline
\end{tabular}

Table 1.54: Variables defining Transformative Resilience PC8

\begin{tabular}{|l|l|l|}
\hline Variable & $\begin{array}{l}\text { Component } \\
\text { Loading }\end{array}$ & Survey Questions \\
\hline q62n & 0.488 & $\begin{array}{l}\text { Q 6.2 Boys and girls are given equal opportunity to attend } \\
\text { school? }\end{array}$ \\
\hline q619 & 0.398 & $\begin{array}{l}\text { Q } 6.19 \text { Do you participate in decision making in this } \\
\text { household (ask only if respondent is a woman) }\end{array}$ \\
\hline q67n & -0.330 & $\begin{array}{l}\text { Q 6.7 Local leaders aware of the different needs of } \\
\text { women and men }\end{array}$ \\
\hline
\end{tabular}

Transformative Resilience Principal Component 9: Women's Empowerment and Access to Farming Inputs

This component describes households that have weak to moderate tendencies for women participate in decision-making and for the household to have access to farming inputs. There are also weak tendencies for women not to have experienced household violence, to hold leadership positions and to indicate that they would report gender-based violence.

Table 1.55: Variance explained for Transformative Resilience PC9

\begin{tabular}{|l|l|l|l|}
\hline Component & Initial Eigenvalues & \multicolumn{2}{|l|}{ Extraction Sums of Squared Loadings } \\
\hline & Total & $\%$ of Variance & Cumulative \% \\
\hline 9 & 1.004 & 3.345 & 68.418 \\
\hline
\end{tabular}


Appendix 1: Principal component descriptions and variable loadings

Table 1.56: Variables defining Transformative Resilience PC9

\begin{tabular}{|l|l|l|}
\hline Variable & $\begin{array}{l}\text { Component } \\
\text { Loading }\end{array}$ & Survey Questions \\
\hline q619 & 0.460 & $\begin{array}{l}\text { Q 6.19 Do you participate in decision making in this } \\
\text { household (ask only if respondent is a woman) }\end{array}$ \\
\hline q33_all_binary & 0.376 & $\begin{array}{l}\text { Q 3.3 During the last planting season (six months), which } \\
\text { of the following farming inputs were you able to } \\
\text { access/receive? }\end{array}$ \\
\hline q629-q630_all & 0.373 & $\begin{array}{l}\text { Q 6.29-6.30 Which group or community structures do hold } \\
\text { leadership position in? }\end{array}$ \\
\hline binary & 0.363 & $\begin{array}{l}\text { Q 6.27 If you suspected that a girl child or woman in the } \\
\text { community was being abused (physically or sexually), } \\
\text { would you willing to report such an incident? }\end{array}$ \\
\hline q621 & 0.305 & $\begin{array}{l}\text { Q 6.21 Over the last 6 months, did you or any female } \\
\text { household member experience any form of Gender based } \\
\text { violence }\end{array}$ \\
\hline
\end{tabular}

